\title{
Sovereign Risk and Asset Market Dynamics in the Euro Area
}

Erica Perego

\section{Highlights}

- We study the behavior of euro area asset markets from a macroeconomic perspective.

- We explain the transmission mechanisms that determine the divergence in core and periphery stock-bond returns' comovements during the period 2010-2014.

- We build a DSGE model for the euro area with a banking sector and international asset markets and we estimate sovereign risk from the data.

- The model buffeted by this shock is able to reconcile the empirical evidence on economic and finance dynamics during the sovereign debt crisis. 


\section{Abstract}

This paper studies the behavior of euro area asset market co-movements during the period 2010-2014, through the lens of a DSGE model. The economy is a two-country world consisting of a core and a periphery and featuring an international banking sector, international equity markets, home bias in sovereign bond holdings, and sovereign default. The periphery is buffeted by a sovereign risk shock, whose process is estimated from the data. The model accounts successfully for the divergence in core-periphery correlations between stock and sovereign bond returns. The simulation results indicate that the sovereign risk shock explains $50 \%$ of the increase in sovereign and loandeposit spreads, and $8 \%$ of the decrease in global output during the sovereign debt crisis.

\section{Keywords}

Currency Union, International Financial Markets, Sovereign Risk, General Equilibrium.

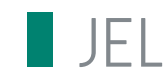

F41, F44, G15

\section{Working Paper}

\section{CEPI}

CEPII (Centre d'Etudes Prospectives et d'Informations Internationales) is a French institute dedicated to producing independent, policyoriented economic research helpful to understand the international economic environment and challenges in the areas of trade policy, competitiveness, macroeconomics, international finance and growth.
CEPII Working Paper

Contributing to research in international economics

C C CEPII, PARIS, 2018

All rights reserved. Opinions expressed in this publication are those of the author(s) alone.

$\begin{array}{ll}\text { Editorial Director: } & \text { CEPII } \\ \text { Sébastien Jean } & \text { 20, avenue de Ségur } \\ & \text { TSA 10726 } \\ \text { Production: } & 75334 \text { Paris Cedex } 07 \\ \text { Laure Boivin } & +33153685500 \\ & \text { www.cepii.fr } \\ \text { No ISSN: } 1293-2574 & \text { Press contact: presse@ }\end{array}$




\title{
Sovereign risk and asset market dynamics in the euro area ${ }^{1}$
}

\author{
Erica Perego (CEPII)*
}

\section{Introduction}

The correlation between stock and bond returns corresponds to a typically time-varying pattern and reflects the changes in agent's decisions according to the business cycle and the different shocks affecting the economy. It is important that both investors and policy makers understand its evolution. From a finance perspective, this correlation implies the presence of risk and calls for diversification of investors' portfolios. From an economic perspective, knowing the effect of macroeconomic dynamics on asset prices contributes to informed policy decisions. Additionally, in a currency union, the correlation between the bond and stock markets, among member countries, reflects the degree of integration of the different economies. In the case of highly integrated economies, this relation should vary in the same way over time. This applied to the euro area until 2009. Figure 1 shows that in the period 2010-2014 the evolution of stock-bond correlations diverged within the European union (EU), demonstrated by an increase in the difference between the periphery and core co-movements (dotted black line). This behavior is consistent with a flight-to-quality in sovereign bond markets from risky periphery bonds to safer core ones, and, conversely, a stable high correlation among EU stock markets. ${ }^{2}$ Table 1 summarizes these stylized facts.

In this paper, we study the behavior of core and periphery asset markets in the euro area based on a quantitative model. In particular we explain the divergence in their co-movements during the years 2010-2014 by investigating the underlying propagation mechanisms. To do this, we build a two-country DSGE model with a banking sector and asset markets. This framework is appropriate to account for the multiple linkages between the core and the periphery, and allows in depth study of asset market dynamics from a macroeconomic perspective. The model builds on Enders et al. (2011), Corsetti et al. (2013) and Coeurdacier et al. (2007).

The literature tends to study the correlation between stock-bond returns and sovereign risk separately, from both a theoretical and an empirical perspective. The theoretical literature on open economy financial macroeconomics focuses on the international dimension of asset markets

\footnotetext{
${ }^{1}$ We thank Axelle Arquié, Vincent Bodart, Hafedh Bouakez, Antonio Cosma, Jérôme Héricourt, Paul Hubert, Luca Pensieroso, Olivier Pierrard, Cèline Poilly, Daniele Siena, Henri Sneessens and Fabien Tripier for useful comments. We also thank Labex MME-DII (ANR-11-LBX-0023-01) for the financial support.

*erica.perego@cepii.fr

${ }^{2} A p p e n d i x A$ and $B$ explain the data in more detail.
} 
(see an exhaustive review in Coeurdacier and Rey (2013)). Closer to our approach is the literature strand dealing with the hedging properties of bonds and equities. However, the models in this literature, do not focus on the specificity of the euro area, and do not consider the risk of default on sovereign bonds. DSGE models used to study the impact of sovereign default consider the pricing of debt (Juessen et al., 2016), the role of debt maturity (Auray and Eyquem, 2018), and the transmission of a sovereign default through the banking sector (van der Kwaak and van Wijnbergen, 2014; Bocola, 2016; Faia, 2017) in close economies. Very few papers analyze the impact of sovereign default at the euro area level, and those that do focus on explaining transmission through the banking sector (Guerrieri et al., 2012), or the stabilizing effect of monetary and fiscal policies (Auray et al., 2018; Corsetti et al., 2014). In this respect, ours is the first paper to examine the impact of sovereign risk also on equity markets. ${ }^{3}$

The empirical literature extensively analyzes the macroeconomic determinants of euro area stockbond co-movements. Among others, Kim et al. (2006) and Andersson et al. (2008) explain the role of variables such as inflation, GDP growth and market uncertainty as the main drivers of the correlations. Perego and Vermeulen (2016) document the heterogeneous behavior of the stockbond correlation in the euro area during the sovereign debt crisis, and among the determinants highlight the role of relative imbalances and diverging fundamentals. There is also a broad empirical literature on sovereign risk which examines i) the pricing of risk (Delatte et al., 2012) and contagion (Beirne and Fratzcher, 2013); ii) the impact of sovereign credit-default swaps (CDS) on bank CDS (Alter and Beyer, 2014) and bank lending (Bofondi et al., 2018; De Marco, 2017; Popov and van Horen, 2015); and iii) stock market prices (Grammatikos and Vermeulen, 2012). At the euro area level and closer to our approach, Neri and Ropele (2013) quantify the transmission of a sovereign risk shock onto periphery and core real economies but they ignore equity markets. This paper tries to fill this gap from a theoretical point of view.

We make two contributions. First, we explain the mechanism of transmission of a sovereign risk shock in euro area asset markets (bond and stock) and the underlying macroeconomic dynamics, by building a comprehensive framework able to reconcile economic and finance perspectives. Second, based on the data we estimate the sovereign risk shock process following the approach in de Grauwe and Ji (2013), and feed this into the model. We show that the model is able to reproduce the divergence in the stock-bond returns correlations in the core and in the periphery, and that the sovereign risk shock is able to explain $50 \%$ of the increase in sovereign and loandeposit spreads, and $8 \%$ of the decrease in global output during the sovereign debt crisis.

The remainder of the paper is structured as follows. Section 2 describes the model, section 3 discusses the model calibration, and section 4 presents the dynamic simulations. Section 5

\footnotetext{
${ }^{3}$ Additionally, general equilibrium models in the macro-finance literature look at the term structure of bond interest rates and the asset pricing of stock and bonds in closed economies. Good reviews of the stock-bond asset pricing literature are provided in Campbell et al. (2014) and Swanson (2015).
} 
Figure 1 - Core and Periphery stock-bond correlations

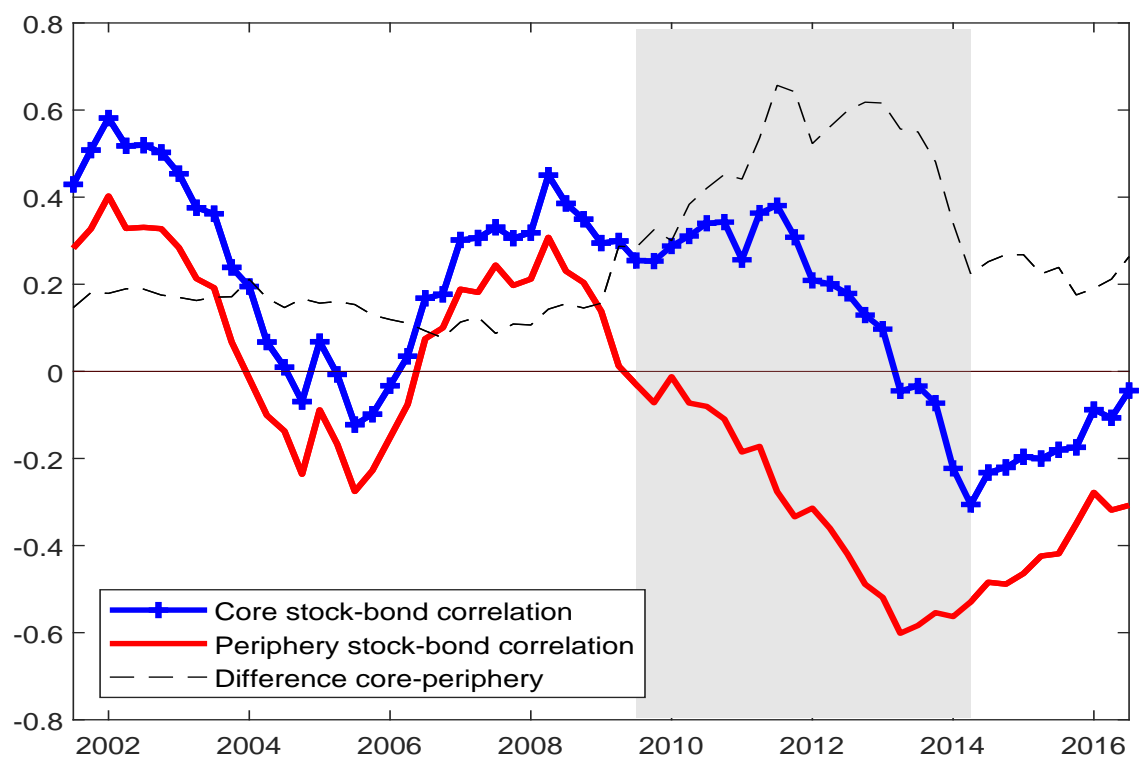

Notes. Stock market series are total return indexes on non-financial firms; bond series are benchmark 10 year indexes of yields to redemption. Core countries are: Austria, Belgium, Finland, France, Germany and the Netherlands. Periphery countries include: Greece, Ireland, Italy, Portugal and Spain. The series are centered on 3 year moving averages on quarterly correlations constructed over daily returns. The series are aggregated at the core and periphery levels as weighted averages based on GDP values for 2004 Q4. The shaded areas highlight the period of the sovereign debt crisis.

Data source: Datastream and author's calculations.

concludes the paper.

\section{Model}

We develop an international business cycle model for the euro area. It consists of two regions, we call the first country/region the core and denote it by $c$. We call the second country/region the periphery and denote it by $p$. The model features an international banking sector, an equity market, and a probability of default on sovereign debt.

We assume symmetrical regions apart from a higher level of debt to output in the periphery. Appendix $\mathrm{E}$ provides a detailed description of the model and the list of equilibrium equations.

\subsection{Households}

Households in each country $j \in\{c, p\}$, maximize their lifetime utility subject to a budget constraint. ${ }^{4}$ The representative household can consume $C_{t}^{j}$ (a bundle of domestic and foreign goods), and invest $D_{t}^{j}$ in one-period bank deposits, or $b_{t}^{h, j}$ in one-period sovereign debt. Households also

\footnotetext{
${ }^{4}$ Agents have a utility function in line with Greenwood et al. (1988) (GHH hereafter) based on consumption, leisure and deposits. The choice of GHH utility is motivated by the international framework since the absence of a wealth effect on labor supply helps in the matching of a series of empirical regularities as explained by Garcia-Cicco et al. (2010), Raffo (2008) and Schmitt-Grohe and Uribe (2012). The results do not change qualitatively if we use a different utility formulation (e.g. KPR).
} 
Table 1 - Correlation data

\begin{tabular}{lccc}
\hline \hline & $2000-2009$ & $2010-2014$ & $2000-2017$ \\
\hline $\operatorname{corr}\left(R^{b, p}, R^{b, c}\right)$ & 0.93 & 0.27 & 0.70 \\
$\operatorname{cor}\left(R^{S, p}, R^{S, c}\right)$ & 0.79 & 0.70 & 0.76 \\
$\operatorname{cor}\left(R^{b, c}, R^{S, c}\right)$ & 0.25 & 0.12 & 0.16 \\
$\operatorname{cor}\left(R^{b, p}, R^{S, p}\right)$ & 0.10 & -0.38 & -0.09 \\
$\operatorname{corr}(S b, c)-\operatorname{corr}(S b, p)$ & 0.14 & 0.50 & 0.26 \\
\hline
\end{tabular}

$R^{b, j}$ is the gross return on sovereign bonds; $R^{S, j}$ is the gross return on equity in country $j \in\{c, p\}$. $\operatorname{Corr}(S b, c)$ - $\operatorname{corr}(S b, p)$ is the difference between the stock-bond correlation in the core $\left(\operatorname{corr}\left(R^{b, c}, R^{S, c}\right)\right)$ and the periphery $\left(\operatorname{corr}\left(R^{b, p}, R^{S, p}\right)\right)$.

can invest in international financial markets, in both domestic and foreign equity $S_{i, t}^{j}$ issued by the respective firms' capital producers $i \in\{c, p\} .{ }^{5} 6$ By investing in deposits the households obtain $R_{t-1}^{d, j}$, the predetermined gross return on deposits. The expected gross return on sovereign bond is $R_{t-1}^{b, j}$ while the actual net return is $R_{t-1}^{b, j}\left(1-\Delta_{t}^{j}\right)$, where $\Delta_{t}^{j} \geq 0$ captures the share of outstanding sovereign debt lost by households due to sovereign default. The expected return on equity holdings is given by the price at which households can sell the share $\rho_{s, t}^{j}$ bought in the previous period, and the dividend payout $d i v_{t}^{j}$, from the capital producers. $Q_{j, t}^{i}$ is the real exchange rate of country $i$ when country $j$ is the numeraire. Households also supply $h_{t}^{j}$ hours to firms and receive a wage $w_{t}^{j}$. In addition, they own the non-financial firms located in $j$ and receive their profits $\Upsilon_{t}^{j}$. Finally, households receive a lump-sum transfer $H_{t}^{h, j}$ from government, and also have to pay taxes $T_{t}^{j}$ as well as a quadratic portfolio adjustment cost on sovereign debt represented by the parameter $\phi_{b}>0 .{ }^{7}$ Additionally, households pay a cost related to their equity holdings represented by the parameter $\phi_{s}>0 .{ }^{8} 9$ These costs make the households' portfolio choices less sensitive to interest rate differentials.

We introduce deposits in the utility function in order to identify the core and periphery deposit Euler equations as in Enders et al. (2011). Based on this formulation, deposits play the role of real cash value: an increase in deposits increases households' payments means and (ceteris paribus) increases their consumption.

${ }^{5}$ In order to reproduce the existence of home bias in sovereign debt holdings, households are assumed to invest only in domestic bonds. Cross-country sovereign bonds holdings are related mainly to banks.

${ }^{6}$ Households' deposit, bond and equity prices are expressed in terms of the corresponding consumption bundles.

${ }^{7}$ This cost is introduced to establish the steady state level of households' sovereign debt holdings.

${ }^{8}$ This cost is introduced to calibrate the steady state value of equity returns and to ensure model stationarity. We can interpret it as mimicking the preferences for a diversified portfolio. If the share holdings deviate from the optimal reference value, households bear an additional cost which leads them optimally to choose to hold the same amount of $c$ and $p$ shares in equilibrium.

${ }^{9}$ Values of $\phi_{b}$ and $\phi_{s}$ close to zero do not qualitatively change the asset market correlations' results. 
The households first order conditions (FOCs) can be written as:

$$
\begin{gathered}
\psi_{n}\left(h_{t}^{j}\right)^{\eta}=w_{t}^{j}, \\
\lambda_{t}^{j}=\frac{\psi_{d}}{D_{t}^{j}}+E_{t} \beta \lambda_{t+1}^{j} R_{t}^{d, j}, \\
\lambda_{t}^{j}\left(1+\phi_{b}\left(b_{t}^{h, j}-\bar{b}^{h, j}\right)\right)=E_{t} \beta \lambda_{t+1}^{j} R_{t}^{b, j}\left(1-\Delta_{t+1}^{j}\right), \\
\lambda_{t}^{j}\left(1+\phi_{s} S_{j, t}^{j}\right)=E_{t} \beta \lambda_{t+1}^{j}\left(R_{j, t+1}^{S}\right), \\
Q_{j, t}^{i} \lambda_{t}^{j}\left(1+\phi_{s} S_{i, t}^{j}\right)=E_{t} \beta \lambda_{t+1}^{j}\left(R_{i, t+1}^{S}\right) Q_{j, t+1}^{i},
\end{gathered}
$$

where $i \neq j, \lambda_{t}^{j}$ is the marginal utility of consumption, and $\beta$ is the subjective discount factor.

Equation (1) shows that the wage is equal to the marginal dis-utility of the hours worked. Equations (2), (3), (4), and (5) state that, at equilibrium, marginal costs are equal to the expected marginal income from, respectively, deposits, sovereign bonds, and domestic and foreign equity. Equation (4) represents the FOC for equity holding for country $j$ households with respect to country $j$ issuers, and (5) represents the FOC for equity holding for country $j$ households with respect to country $i, i \neq j$.

The expected real return on equity for both countries $j$ is:

$$
E_{t}\left[R_{j, t+1}^{S}\right]=\frac{E_{t}\left[\rho_{j, t+1}^{S}\right]+E_{t}\left[d i v_{j, t+1}\right]}{\rho_{j, t}^{S}} .
$$

Equity returns are defined as the change in the equity price plus the dividend payouts.

\subsection{Capital producers}

The capital producers in country $j \in\{c, p\}$ have the choice to obtain funding by demanding a one-period loan from the bank or issuing equity on the international asset market. In the latter case, they may pay dividends, $d i v_{t}^{j}$, to households or retain the earnings and invest, $I_{t}^{j}$, in the domestic firms. In turn, investments increase firms' capital stock, $K_{t}^{j}$, according to the following law of motion:

$$
K_{t}^{j}=(1-\delta) K_{t-1}^{j}+I_{t}^{j}
$$

where $0<\delta<1$ is the capital's depreciation rate. Investing in capital is remunerated by a net real return $r_{t}^{j}$, while for loans capital producers pay a gross real interest rate $R_{t-1}^{l, j}$. They are obliged also to pay an adjustment cost on the investment represented by the parameter $\phi_{i}>0$, 
10 and a dividend payout cost represented by the parameter $\kappa_{d}$. As in Jermann and Quadrini (2012), the equity payout cost can be interpreted as both a pecuniary cost and a way of modeling the speed of the fund's adjustment if financial conditions change. When $\kappa_{d}$ is infinitely large, capital producers have access to only one source of funds, i.e. bank loans. For smaller values, as in the case examined in this paper, capital producers can be financed by both retained earnings and bank loans. ${ }^{11}$

Capital producers maximize the present discounted value of future dividends yielding the following FOC:

$$
\begin{gathered}
\lambda_{t}^{e, j}=E_{t} \beta^{e, j} \lambda_{t+1}^{e, j} R_{t}^{l, j}, \\
\lambda_{t}^{e, j} q_{t}^{j}=E_{t} \beta^{e, j} \lambda_{t+1}^{e, j}\left(r_{t+1}^{j}+(1-\delta) q_{t+1}^{j}\right), \\
l_{t}^{j}=\bar{l}^{j}+\frac{1}{\phi_{l}}\left(q_{t}^{j}-1\right),
\end{gathered}
$$

where $\lambda_{t}^{e, j}$ is the Lagrangian multiplier associated to the capital producers' budget constraint and $\beta^{e, j}$ is the entrepreneur's discount factor. ${ }^{12}$

Equation (8) states that, at equilibrium, the marginal income from loans is equal to the expected marginal cost. Equation (9) defines the shadow value of capital, $q_{t}^{j}$, as the expected discounted value of the marginal profits from having one additional unit of capital. If $q_{t}^{j}<1$, meaning that the shadow value of capital is lower than the price of capital, equation (10) states that investments will decline; if $q_{t}^{j}>1$ then investments should increase. ${ }^{13}$

\subsection{Nonfinancial firms}

In each country $j \in\{c, p\}$ firms are perfectly competitive. The intermediate $j$ firm produces a good that is sold in both the domestic and the foreign country. A final firm in each country combines the intermediate goods from the $j$ and $-j$ countries into a final good.

In each region, the demand for goods is a composite of home and foreign intermediate goods.

\footnotetext{
${ }^{10} \mathrm{~A}$ convex adjustment cost on investment is commonly used in the literature because it tends to match the empirical behavior of aggregate investment, and prevents the investment demand curve from being perfectly elastic. For some early work that assumes this cost see among others Gould (1968) and Lucas (1967).

${ }^{11} \mathrm{High}$ values of $\kappa_{d}$ impose a high cost on capital producers if they want to adjust the dividend payouts from their steady state value. Lower values allow more flexibility in the payout policy and firms can decide to reduce the payout in order to use the retained earnings to finance investment in place of a bank loan.

${ }^{12}$ Since equity shares are held internationally, capital producers are owned by the households in both the core and periphery countries. As a consequence, the discount factor is a time-varying weighted average (where the weights are the amount of shares each household holds in one country's capital producers) of core and periphery households' marginal utilities. See appendix E for more details.

${ }^{13}$ This formulation of the investment equation follows Tobin's $Q$ theory of investment (Tobin, 1969).
} 
The aggregate demand for country $j$ is:

$$
A^{j}=\left(\frac{A_{j}^{j}}{1-\alpha}\right)^{(1-\alpha)}\left(\frac{A_{-j}^{j}}{\alpha}\right)^{\alpha}
$$

where $A_{j}^{j}$ and $A_{-j}^{j}$ are respectively the demands of the final firm $j$ for goods $j$ and $-j .0<$ $1-\alpha<1$ is the degree of home bias, or alternatively, can be interpreted as an index of country openness.

The welfare based price index (for both regions) corresponding to these preferences is:

$$
P_{t}^{j}=\left(p_{j, t}^{j}\right)^{(1-\alpha)}\left(p_{-j, t}^{j}\right)^{\alpha}
$$

The production function for the intermediate tradable good is a Cobb-Douglas whose inputs are capital and labor rented respectively from capital producers and households:

$$
Y_{t}^{j}=Z_{t}^{j}\left(K_{t}^{j}\right)^{\mu}\left(h_{t}^{j}\right)^{1-\mu}
$$

where $Z_{t}^{j}$ represents total factor productivity (assumed to be constant at $\bar{Z}^{j}=1$ ) and $0<$ $\mu<1$ is the elasticity of output to capital. Intermediate firms maximize their profits given their production technology. The FOC equate the marginal productivity of factors to their marginal cost:

$$
\begin{aligned}
r_{t}^{j} & =\mu \frac{\phi_{t}^{j} Y_{t}^{j}}{K_{t-1}^{j}} \\
w_{t}^{j} & =(1-\mu) \frac{\phi_{t}^{j} Y_{t}^{j}}{h_{t}^{j}}
\end{aligned}
$$

with $\phi_{t}^{j}=\frac{p_{j, t}^{j}}{P_{t}^{j}}$ being the share of domestic produced goods' prices in the domestic price index.

\subsection{Banking sector}

The banking sector is represented by an international and perfectly competitive bank à la Enders et al. (2011). The bank is located in the core but trades with all countries $j \in\{c, p\}$. It collects deposits $D_{t}^{j}$ from households and can invest in sovereign bonds $b_{t}^{b, j}$ and can provide loans $L_{t}^{j}$ to the firms in both regions. ${ }^{14}$ The bank maximizes its consumption (its profits) over the two regions, and consumes a corresponding bundle of core and periphery goods. The bank faces a capital requirement to set aside a fraction $0<\gamma<1$ of its loans as own capital. The bank's

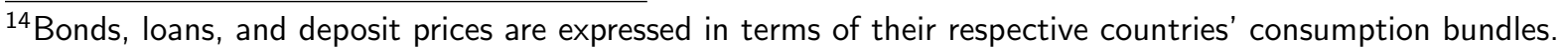


balance sheet constraint is:

$$
(1-\gamma) \sum_{j} Q_{c, t}^{j} L_{t}^{j}+\sum_{j} Q_{c, t}^{j} b_{t}^{b, j}=\sum_{j} Q_{c, t}^{j} D_{t}^{j}+x_{t}
$$

where $x_{t}$ is the bank's excess capital at the end of period $t$. The bank can deviate from these legal requirements $\left(x_{t}=0\right)$ but this is costly. ${ }^{15}$

The bank pays an interest rate $R_{t-1}^{d, j}$ on deposits, it receives $R_{t-1}^{l, j}$ on loans and $R_{t-1}^{b, j}$ on sovereign bonds. Sovereign bonds are risky assets since government can default on a fraction $\Delta_{t}^{j}$ of the debt. The bank might receive a lump-sum transfer $H_{t}^{b, j}$ from government. Moreover, the bank faces different types of costs: operational costs on deposits as in Enders et al. (2011), captured by $\Gamma_{d}$; adjustments costs on loans, $\Gamma_{l}$, as in Guerrieri et al. (2012); ${ }^{16}$ and the cost of deviating from the legal requirement which, following Enders et al. (2011), we capture by $\Gamma_{x}>0$.

The FOC are:

$$
\begin{gathered}
Q_{c, t}^{p}=\frac{1-\vartheta}{\vartheta} \frac{C_{t}^{b, c}}{C_{t}^{b, p}}, \\
\lambda_{t}^{b}\left(Q_{c, t}^{j}-\Gamma_{d}+Q_{c, t}^{j} \Gamma_{x} x_{t}\right)=\beta E_{t} \lambda_{t+1}^{b} Q_{c, t+1}^{j} R_{t}^{d, j}, \\
\lambda_{t}^{b}\left(Q_{c, t}^{j}+\Gamma_{l}\left(L_{t}^{j}-\bar{L}^{j}\right)+(1-\gamma) Q_{c, t}^{j} \Gamma_{x} x_{t}\right)=\beta E_{t} \lambda_{t+1}^{b} Q_{c, t+1}^{j} R_{t}^{l, j}, \\
\lambda_{t}^{b}\left(Q_{c, t}^{j}+Q_{c, t}^{j} \Gamma_{x} x_{t}\right)=\beta E_{t} \lambda_{t+1}^{b} Q_{c, t+1}^{j} R_{t}^{b, j}\left(1-\Delta_{t+1}^{j}\right),
\end{gathered}
$$

where $\lambda_{t}^{b, j}$ is the Lagrangian multiplier associated to the bank's budget constraint.

Equation (17) shows that the bank's consumption ratio for the two regions depends on the relative consumption price index ratio. Equations (18), (19), and (20) represent respectively the Euler equations for deposits, loans, and sovereign bonds.

\subsection{Government}

Government consumption in each region $j \in\{c, p\}, G^{j}$, is financed via lump-sum taxes, $T_{t}^{j}$, from households, and by public debt, $B_{t}^{j}$, according to:

$$
G^{j}+H_{t}^{h, j}+H_{t}^{b, j}+R_{t-1}^{b, j}\left(1-\Delta_{t}^{j}\right) B_{t-1}^{j}=B_{t}^{j}+T_{t}^{j}
$$

\footnotetext{
${ }^{15}$ As in Enders et al. (2011), the penalty function is a convex function of $x_{t}$ ensuring the existence of a convenience yield over the deposit rate and ensuring that the loan spread is decreasing in $x_{t}$. We assume a quadratic function $\phi=\frac{\Gamma_{x}}{2}(x)^{2}$ with the following properties: $\phi(0)=0$ and $\phi^{\prime \prime} \geq 0$.

${ }^{16}$ Deposit and loan costs are introduced to establish the steady state level of, respectively, deposit interest rates and the loans volume.
} 
$\Delta_{t}^{j}$ is the part of sovereign bonds on which government might default. Following Corsetti et al. (2013), we assume that government transfers $H_{t}^{h, j}=\Delta_{t}^{j} R_{t-1}^{b, j} b_{t-1}^{h, j}$ to households and $H_{t}^{b, j}=$ $\Delta_{t}^{j} R_{t-1}^{b, j} b_{t-1}^{b, j}$ to banks to compensate their losses. The transfers ensure that the default is neutral ex-post in terms of its distributional effects across agents and that there is no relaxation of the pressure on the stock of debt as can be seen from the consolidated budget constraint:

$$
\begin{aligned}
G^{j}+R_{t-1}^{b, j} B_{t-1}^{j} & =B_{t}^{j}+T_{t}^{j} \\
T_{t}^{j} & =\bar{T}+\tau\left(B_{t}^{j}-\bar{B}\right) .
\end{aligned}
$$

However, agents do not anticipate when and how much the transfers (lump-sum) will be. Therefore, default is not neutral ex-ante: the probability of default affects the pricing of debt increasing the sovereign bond interest rate. Because of the higher cost of servicing the debt, debt accumulation increases and calls for a stabilization mechanism. Thus, default risk affects the real economy.

We assume that the stability of public debt is ensured by a tax rule. ${ }^{17}$ This implies that government cannot finance public expenditure only via debt. ${ }^{18}$ Finally and for simplicity, we define public expenditures as a fixed fraction, $G^{j}$, of the debt in all periods. ${ }^{19}$

\subsubsection{Sovereign risk shock}

To determine the default rate $\Delta_{t}^{j}$ we adhere to the methodology in Corsetti et al. (2013) by introducing an exogenous fiscal limit for the economy. ${ }^{20}$ The underlying intuition is that there exists a maximum level of taxes that can be raised before the economy becomes politically unstable. This translates into a maximum level of the sovereign debt-to-output ratio $B Y_{t}^{\max }$ which government is able to service. Moreover, we assume that this maximum sustainable level is stochastic and follows:

$$
B Y_{t}^{\max }=\overline{B Y^{\max }}+\gamma_{b}\left(B Y_{t-1}^{\max }-\overline{B Y^{\max }}\right)+u_{t}^{b}
$$

where $0<\gamma_{b}<1$ is the autoregressive component, and $u_{t}^{b}$ is an i.i.d. shock. This stochastic behavior captures the uncertainty related to political instability in the context of sovereign debt and taxation. ${ }^{21}$

\footnotetext{
${ }^{17}$ As estimated by Bohn (1998), taxes react positively to an increase in debt so to stabilize it.

${ }^{18}$ We use the same stabilization mechanism as in Corsetti et al. (2013). However, since we do not focus on the fiscal dimension we use debt-smoothing lump-sum taxes rather than more complicated distortionary tax schemes. ${ }^{19}$ An alternative stabilization method could pass through a reduction in public expenditure rather than an increase in taxes. Both methods have an impact on domestic demand and deliver quantitatively similar results.

${ }^{20}$ The concept of exogenous fiscal limit was introduced by $\mathrm{Bi}$ (2012).

${ }^{21}$ In reality, the maximum sustainable government debt level is not exogenous but depends on expected growth rates, on expected growth volatility, and on government's expected ability to raise taxes (see e.g. Collard et al. (2015)). All these factors affect the economic fundamentals. However, since in this paper we consider only
} 
Let us define $\tilde{B}_{t}^{j}$ as the level of debt in the economy when there is no default. If the corresponding level of debt-to-output $\tilde{B}_{t}^{j} /\left(4 Y_{t}^{j}\right)$ is lower (resp. higher) than the maximum sustainable level $B Y_{t}^{\max }$, the government does not (resp. does) default. We approximate the probability of default by the continuous normal cumulative distribution function (cdf):

$$
\epsilon_{t}^{j}=F\left(\frac{\tilde{B}_{t}^{j}}{4 Y_{t}^{j}}-B Y_{t}^{\max } ; 0, \sigma^{2}\right)
$$

where $\sigma^{2}>0$ represents the variance and $0 \leq \epsilon_{t}^{j} \leq 1$. A reduction (resp. increase) in the maximum sustainable level of debt-to-output, through the stochastic shock $u_{t}^{b}$ in equation (24), increases (reduces) the default probability in the economy. Similarly, a higher (resp. lower) debt-to-output ratio $\tilde{B}_{t}^{j} /\left(4 Y_{t}^{j}\right)$ increases (resp. reduces) the default probability in the economy.

The default process becomes:

$$
\Delta_{t}= \begin{cases}1 & \text { with probability } \epsilon_{t}^{j} \\ 0 & \text { with probability } 1-\epsilon_{t}^{j} .\end{cases}
$$

The ex-post neutrality feature is necessary to capture the risk dimension of the sovereign debt crisis during which the probability of default and sovereign bond interest rate increase without actual renege on the debt contract. In this way, we isolate the effect of a change in the probability of default, agents' expectations, and an increase in bond interest rates from the (additional) consequences of a repayment loss. ${ }^{22} 23$

\subsection{Closing the model}

\subsubsection{Asset market clearing conditions}

The sovereign bond market clearing condition for country $j \in\{c, p\}$ is:

$$
B_{t}^{j}=b_{t}^{h, j}+b_{t}^{b, j}
$$

where $b_{t}^{h, j}$ and $b_{t}^{b, j}$ are the respective quantities of bonds held by households and the bank.

The equity market clearing condition for issuing country $i \in\{c, p\}$ and the holding country

business cycle fluctuations, we assume that the structure of the economy does not change in the short run, and we study only fluctuations around the trend. This modeling is in line with other studies that use the concept of natural debt limit in business cycle models, see e.g. van der Kwaak and van Wijnbergen (2014); Corsetti et al. (2013) among the others.

${ }^{22}$ This specification is used in Corsetti et al. (2013). This procedure is helpful to reproduce the dynamics of the euro area sovereign debt crisis when effectively only Greece partially defaulted.

${ }^{23}$ Appendix $\mathrm{D}$ shows the implications of relaxing the assumption of ex-post default neutrality. 
$j \in\{c, p\}$ is:

$$
1=S_{i, t}^{j}+S_{i, t}^{-j}
$$

implying that there is a fixed number of shares traded in the economy normalized to 1 .

\subsubsection{Good market clearing condition}

Let us define the country j's domestic demand as:

$$
A_{t}^{j}=C_{t}^{j}+C_{t}^{b, j}+l_{t}^{j}+G_{t}^{j}+\operatorname{cost} s_{t}^{j}
$$

where $\operatorname{costs} s_{t}^{j}$ collects all adjustment and operating costs borne by the households, capital producers, and firms in country $j$. $\operatorname{costs}_{t}^{c}$ also includes bank related costs.

The goods market clearing condition for each region $j$ is:

$$
Y_{t}^{j}=A_{j, t}^{j}+A_{j, t}^{-j}
$$

where $A_{j, t}^{-j}$ is the demand of agent $-j$ for good $j$ and $A_{j, t}^{j}$ is the demand for good $j$ from $j$ agents.

By summing them we obtain the resource constraint for the two-country economy:

$$
\sum_{j} \phi_{t}^{j} Q_{c, t}^{j} Y_{t}^{j}=\sum_{j} Q_{c, t}^{j} A_{t}^{j}
$$

which shows that total production has to be equal to demand in the whole currency area.

\section{Calibration}

Table 2 presents the model parameters. Most of the values are the same as those used in the DSGE and sovereign default literature. The calibration refers to euro area stylized facts during the period 1992Q1-2017Q2. Time is discrete, and one period represents one quarter. We specify the two country model for the euro area distinguishing between the core and the periphery in terms of debt-to-output ratio. The periphery refers to the GIIPS (Greece, Ireland, Italy, Portugal and Spain) where we assume a higher debt to GDP ratio with respect to the core (Austria, Belgium, Finland, France, Germany and the Netherlands). We assume the same size for the core and periphery area in order to focus on the main asymmetry produced by differentials in debt levels. ${ }^{24}$ Unless otherwise specified we opt for the same parameter choices in the two country blocs.

\footnotetext{
${ }^{24}$ Data for the euro area period suggest that the core output accounts for about $63 \%-67 \%$ of euro area output and that periphery output accounts for the remaining 33\%-37\%. Calibrating the model to account for different core and the periphery sizes would change the model steady state but not its dynamics.
} 
Table 2 - Parameter values

Parameter Value Description

Households

$\begin{array}{ccl}\beta & 0.99 & \text { Discount factor } \\ \phi_{b} & 0.1 & \text { Bond adjustment cost } \\ \phi_{s} & 0.01 & \text { Stock holding cost } \\ \psi_{n} & 219 & \text { Weight of labour in (dis-)utility } \\ \psi_{d}^{c} & 0.068 & \text { Weight of deposits in utility } \\ \psi_{d}^{p} & 0.048 & \text { Weight of deposits in utility } \\ \eta & 4 & \text { Inverse of the intertemporal elasticity of labour supply }\end{array}$

Global bank

$\begin{array}{ccl}\vartheta & 0.5 & \text { Elasticity of utility w.r.t. country c consumption goods } \\ \gamma & 0.08 & \text { Bank capital ratio requirement } \\ \Gamma_{d} & 0.005 & \text { Deposit operating cost } \\ \Gamma_{I} & 0.001 & \text { Loan adjustment cost } \\ \Gamma_{x} & 0.105 & \text { Capital requirement cost }\end{array}$

Production

$\begin{array}{ccl}\delta & 0.025 & \text { Capital depreciation rate } \\ \phi_{i} & 0.1 & \text { Investment adjustment cost } \\ \kappa_{d} & 0.04 & \text { Dividend adjustment cost } \\ \alpha & 0.3 & \text { Index of openess } \\ \mu & 0.3 & \text { Elasticity of production w.r.t. capital }\end{array}$

Authorities

$\begin{array}{ccl}\tau & 0.13 & \text { Elasticity of taxes w.r.t. debt } \\ \bar{G}^{j} / \bar{Y}^{j} & 0.20 & \text { Public consumption-output ratio objective } \\ \bar{B}^{c} /\left(4 \bar{Y}^{c}\right) & 0.60 & \text { Debt-output ratio objective in the core country } \\ \bar{B}^{p} /\left(4 \bar{Y}^{p}\right) & 0.85 & \text { Debt-output ratio objective in the periphery country } \\ \overline{B Y}^{\max } & 0.92 & \text { Maximum sustainable debt-output ratio } \\ \sigma & 0.015 & \text { Standard deviation of default pdf }\end{array}$

Shock

$\gamma_{b} \quad 0.8354$ Autoregressive parameter for the maximum sustainable debt level 


\subsection{Parameters governing the steady state}

At the steady state all the agents in the economy discount the future via the same discount factor $\beta$ as $\bar{\beta}^{e}=\beta$. We assume no default at steady state in the core, and very low value default in the periphery, $\bar{\Delta}^{p}=0.054 \%$. Additionally, $\bar{x}=0$ implying no banks' excess capital at steady state. We set $\Gamma_{D}=0.005$ and $\beta=0.99$ in order to obtain the annualized returns on loans and bonds of $4 \%$ and on deposits of $2 \% \cdot{ }^{25}$ Additionally, we set $\phi_{s}$ equal to 0.01 in order to obtain an annualized return on equity of $6 \%{ }^{26}$ given steady state domestic as well as foreign shares holdings of $\bar{S}_{i}^{j}=1-\bar{S}_{i}^{-j}=0.5$. This value is consistent with ECB (2012b) and Jochem and Volz (2011) on the intra-EA home bias in equity holdings which assess a level of cross-border holdings of around $40 \%-60 \%$. In the case of sovereign bond holdings in the euro zone, we follow Guerrieri et al. (2012) and assume that 33\% of sovereign debt is held by domestic households and the remainder by the bank. ${ }^{27}$

We set the required bank capital ratio at $\gamma=0.08$ consistent with the minimum capital requirement of Basel II for Tier 2 capital as this is the regulation in force in both the euro area period and when the sovereign debt crisis started. Finally, the size of the bank balance sheet is $111 \%$ of yearly total output $\left(\bar{Y}^{c}+\bar{Y}^{p}\right)$. This number is in line with the euro area data on bank balance sheets for loans and securities holdings issued by euro area residents.

The loans to physical capital ratio is set at around $1 / 3$ and establishes the household weight on deposits $\Psi_{d}$ as in Enders et al. (2011). $\Psi_{n}$, the dis-utility of the labor parameter, is established by setting $\bar{h}^{j}=0.2$ following the real business cycle (RBC) literature, and implying that households work $20 \%$ of their time. We calibrate $\eta$, the parameter governing the shape of labor dis-utility, in order to have a Frisch elasticity of 0.25 in line with the micro-based measures. ${ }^{28}$ The production function is Cobb-Douglas with the capital share at 0.3 ; setting the depreciation rate at $\delta=0.025$ implies $\bar{K}^{j} / \bar{Y}^{j}=8.54$ and $\bar{I} / \bar{Y}=0.21$ which is in line with the RBC literature and empirical observations. Households consumption in total output is $55 \%$ while the bank consumption is $2.3 \%$. The bank's utility is a Cobb-Douglas combination of the consumption over the two regions. The share of core consumption determined by the parameter $\vartheta$, is set to 0.5 which assumes that bank consumption falls equally in the two regions. Finally, following the New Open Economy Macroeconomics (NOEM) literature and in line with Gali and Monacelli (2008), we

\footnotetext{
${ }^{25}$ These steady state values are set to match the empirical evidence for 10 year bond returns and 5 year maturity loan rates. This choice is based on data availability and allows comparable maturities for these assets.

${ }^{26}$ This value is in line with the annualized returns from the non-financial corporation equity index for euro area countries.

${ }^{27}$ We do not have data on non-residents' holdings of sovereign debt and assume that this debt is held mainly by banks rather than foreign households. A different assumption would not change the implications of the model as long as most households debt is domestic.

${ }^{28} \mathrm{MaCurdy}(1981)$ and Altonji (1986) estimate the Frisch elasticity - determined by hours and wage fluctuations on an individual basis as ranging from 0 to 0.54 . More recently, Chetty et al. (2011) reconcile micro-macro measures of the Frisch elasticity suggesting a value of 0.25 for the labor supply extensive margin.
} 
assume a bias for domestic goods and calibrate $\alpha=0.3<0.5{ }^{29}$

On the fiscal side we distinguish between core and periphery in terms of their debt-to-output ratios: we set it to $85 \%$ for the periphery at steady state, and at $60 \%$ for the core. ${ }^{30}$ Public expenditure is set at $20 \%$ of GDP in line with euro area data. ${ }^{31}$ We set the maximum level of debt $\overline{B Y}^{\max }$ and the standard deviation of default, $\sigma$, to achieve a default risk to debt elasticity of 0.1 around the steady state for the periphery country. ${ }^{32}$

\subsection{Parameters governing the dynamics}

This set of parameters does not affect the steady state but only the model dynamics. ${ }^{33} \mathrm{We}$ assume a GHH utility function for households and a linear function for the bank in order to account for the different levels of risk aversion (higher for households and null for the bank). ${ }^{34}$ Adjustment costs on bonds, loans, and investments $\left(\phi_{b}, \Gamma\right.$, and $\left.\phi_{i}\right)$ are standard in the DSGE literature, and their values are reported in Table $2 .{ }^{35}$

In the bank specification we set $\Gamma_{x}=0.105$, the capital cost parameter, in order to match the impact on the loan-deposit spread of a $1 \%$ increase in regulation. ${ }^{36}$ On the capital producers' side, the adjustment cost on the dividend payout is associated to the parameter $\kappa_{d}$ which, in the benchmark calibration, is set to match the standard deviation of core dividend payout (with respect to GDP). ${ }^{37}$

\footnotetext{
${ }^{29}$ The value selected is in the range of the values applied to recent macro-finance models. See Coeurdacier et al. (2007).

${ }^{30}$ These values are in line with the International Monetary Fund's economic outlook for 2010.

${ }^{31}$ This implies that taxes-to-output are $22 \%$ of GDP in the core and $23 \%$ of GDP in the periphery, the difference being due to the different debt burdens in the two regions which enforces higher taxation in the periphery.

${ }^{32}$ The elasticity of - yearly - default with respect to debt to output implied by the model is:
}

$$
\text { elasticity }^{j}=\frac{4 \Delta \epsilon_{t}^{j}}{\Delta X_{j, t}^{b}}=\frac{4}{\sigma} \phi\left(\frac{\bar{X}_{j}^{b}}{\sigma}\right),
$$

where $\phi($.$) is the standard normal pdf and X_{j, t}^{b}=\frac{\tilde{B}_{t}^{j}}{4 Y_{t}^{j}}-B Y_{t}^{\max }$ with $\bar{X}_{j}^{b}$ its steady state. The methodology used to calibrate the default process follows Corsetti et al. (2013) and uses 10 year sovereign CDS spreads and debt-to-GDP data. The elasticity value of 0.1 is consistent with the empirical stylized facts for the euro area for year 2011.

${ }^{33}$ In each country the sum of all the dynamic costs accounts for $1 \%$ of domestic output.

${ }^{34}$ As a sensitivity analysis we substitute the utility function used in the baseline model with a KPR formulation à la King et al. (1988). Correlation results are unchanged by the new utility specification. The results are also qualitatively consistent with changes in the value of the inter-temporal substitution of consumption. However, the baseline formulation better matches the empirical regularities, given the absence of a wealth effect on the labor supply, and yields correlation results closer to the data estimates.

${ }^{35} \phi_{i}$ controls for the volatility of investments. As its choice, together with $\kappa_{d}$ has an impact on firm choices and equity dynamics, section 4.2 provides a sensitivity analysis.

${ }^{36}$ We set a value of $\Gamma_{x}$ to match a loan-deposit spread increase in the euro area of 15 basis points. Empirical estimates of the reaction of lending spreads to a $1 \%$ regulation shock are in the range 14.3-15.5 basis points. See for instance Slovik and Cournède (2011) and Roger and Vitek (2011).

${ }^{37}$ We choose to match only the core standard deviation in the dividend payout in order to retain a mostly symmetric calibration of the model between the core and the periphery with the exception of the debt to GDP 
In the fiscal rule we follow Corsetti et al. (2013) and set the value of $\tau=0.13$ at a sufficiently high value to ensure that the debt remains bounded during the simulations.

To calibrate the maximum sustainable level of debt shock we identify the part played by the riskiness of the periphery debt that is not explained by the fundamentals, as discussed in appendix C. We calibrate $\gamma_{b}$ in equation (24) to 0.8354 , consistent with the autocorrelation of the maximum sustainable level of debt with respect to output.

\section{Dynamic simulation}

In this section we explain how the sovereign risk shock is identified from the data. We study the propagation of this shock and the economic mechanism at play, adding a sensitivity analysis to the key parameters. Finally, we simulate the model using the estimated shock, and compare the simulated stock-bond market correlations to their empirical counterparts. ${ }^{38}$

\subsection{Sovereign risk shock in the data}

The period 2010-2014 was characterized by a euro zone sovereign debt crisis. Periphery countries experienced increasing sovereign debt problems which were reflected in high interest rates. ${ }^{39}$ Prior to the crisis, measures of debt sustainability, competitiveness and growth were the main determinants of interest rates on sovereign bonds.

However, during the sovereign debt crisis a large part of this risk was no longer explained by these macroeconomic dynamics. To identify this unexplained part of the risk we regress a set of macroeconomic variables on periphery sovereign bond yield spreads -vis-à-vis Germany- following de Grauwe and Ji (2013) and as explained in appendix C. Figure 2, shows that up to 2010 yields (or riskiness vis-à-vis Germany) were explained by the macroeconomic fundamentals as the residuals of the regression are centered around zero. From 2010, the model fits the data less well suggesting that something else is driving the risk. This is the shock we identify and estimate based on the data, and which had a major impact between 2010 and $2014 .{ }^{40}$ In the model, this shock is introduced by computing the value of $u_{t}^{b}$ consistent with the behavior of the unexplained-risky part of the sovereign spreads as shown in figure 2 .

steady state asymmetry. We could calibrate $\kappa_{d}^{c} \neq \kappa_{d}^{p}$ to match data on both the core and periphery dividend payout but this would not change the results qualitatively.

${ }^{38}$ To simulate the model we take a first order approximation of the model equations and solve the model using Dynare 4.4.3. For more information refer to Adjemian et al. (2011).

${ }^{39}$ See appendix A figure A.2.

${ }^{40}$ If we run the panel regression splitting the sample before and after 2010 and compare the $R^{2}$, we see that $R^{2}$ is much lower in the second sample. This provides additional evidence of a change in the model's explanatory power. 
Figure 2 - Yield spreads and sovereign risk shock in the euro area periphery

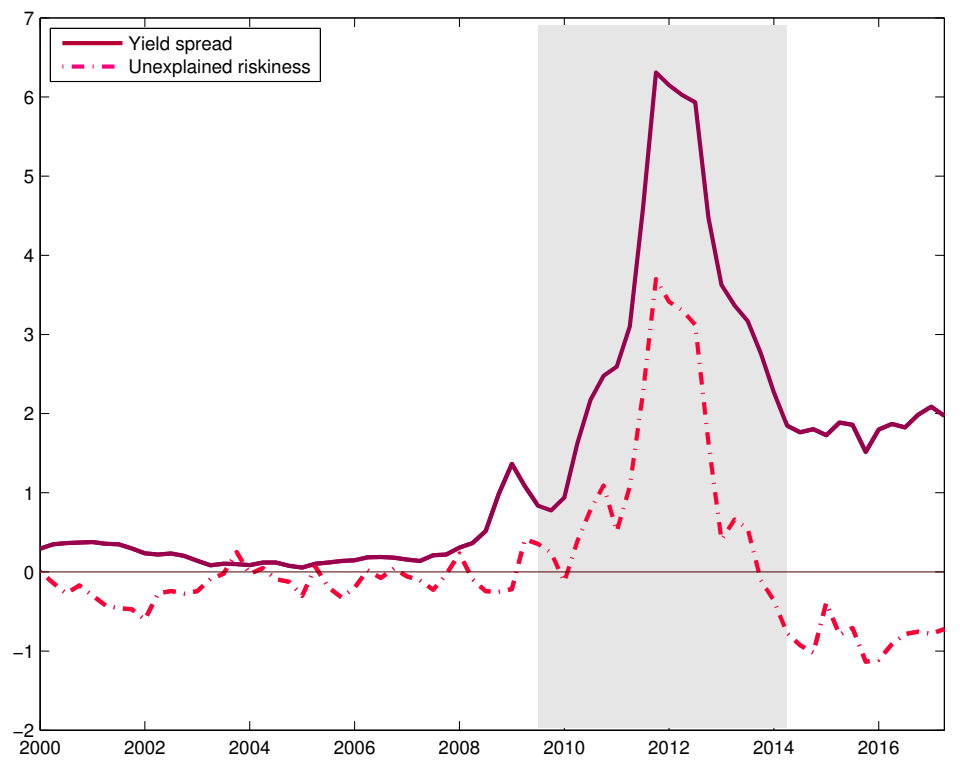

Notes. The figure plots the aggregated yields of periphery countries with respect to Germany (in percentage points) and the residuals from the panel estimation at the aggregated periphery level. The series are weighted averages based on GDP measures as of 2004 Q4. The residuals capture the part of the sovereign yield spreads that is unexplained by changes to the fundamentals, and that identifies the sovereign risk shock. The shaded areas highlight the period of the sovereign debt crisis.

Data sources: Author's calculations.

\subsection{Theoretical responses}

A sovereign risk shock in the periphery is mimicked by a decrease in the maximum level of sustainable debt that determines an increase in the probability of default on periphery sovereign bonds. As soon as agents start to price in the increased default probability, periphery bond interest rates increase as shown in figure 3. Since government compensates the default, agents do not face any loss. However, default expectations matter for agents' decisions under uncertainty. A change to the default probability triggers adjustments to the agents' portfolios based on the ex-ante probability of a default. ${ }^{41}$ Additionally, since bond interest rates are higher, debt accumulation increases because of the higher costs of servicing the debt. The stabilization mechanism then comes into play: taxes increase in the periphery impacting on domestic demand and periphery households. As a consequence, consumption of both domestic and foreign goods decreases.

Given the home biased composition of the household consumption basket, a decrease in consumption in the periphery leads to a reallocation of relative prices and appreciation of the core currency. The marginal productivity of the factors of production falls in the periphery, determining a decrease in labor and output. Furthermore, as the shadow value of capital falls, investments decrease which reduces capital.

\footnotetext{
${ }^{41}$ If there were no uncertainty around default (meaning that the realization of default is known when a bond is bought) and no transfer mechanism at play, an increase in the default probability at time $t$ would be immediately priced within a corresponding increase of the sovereign interest rate, impacting only on the sovereign bond spread.
} 
The global bank is affected by the sovereign risk shock through changes to its balance sheet composition. In order to restore balance sheet parity and profits -since the bank is financially constrained and cannot deviate freely from legal requirements- the bank substitutes sovereign bonds with loans in the face of a decrease in periphery households' deposits and a change in bond returns. ${ }^{42}$ In particular, the bank reduces its periphery sovereign bond holdings determining an increase in the sovereign bond market spread, reflecting the flight to quality between risky (periphery bonds) and riskless (core bonds) sovereign bonds. ${ }^{43}$ A change to the bank balance sheet composition translates also into spread adjustments. Loan-deposit spreads increase in both the core and the periphery transmitting the shock to the core country's real economy.

At the same time, real exchange rate dynamics drive an increase in core imports. As a consequence, the expected value of capital decreases alongside a reduction in core investments and capital. The core country faces a short-lived increase in core employment and output due to temporarily higher wages. However, since core investments fall, output in the core is forced to decrease (after an initial boost) and consumption also falls.

In the case of equity, the decreased investment in both countries determines a fall in equity prices in both regions because the expected discounted value of future dividends decreases due to lower investments. This leads, in turn, to a decrease in equity returns in both regions but one that is more pronounced in the periphery country.

The disruption to the sovereign bond market and the high correlation in the stock market ultimately affect the core and periphery stock-bond correlations in different ways. In the core, the correlation is positive. Following a sovereign risk shock, on the one hand interest rates on bonds are reduced by the flight-to-quality towards this asset, on the other hand, equity returns decrease as firms are affected by a reduction in credit which impacts negatively on investment and output. In the periphery, the correlation is negative as sovereign returns spike while stock

\footnotetext{
${ }^{42}$ The substitution towards loans determines a short-lived decrease in loan rates and an increase in loan supply which is counter-factual (see Bofondi et al. (2018); De Marco (2017); Popov and van Horen (2015)). A complete description of the bank's reaction to a sovereign risk shock should include the additional role of sovereign debt as a source of collateral, as reported in BIS (2011). If banks' funding capacity is constrained by the volume and value of their collateral, a sovereign risk shock will determine a decrease in the availability and eligibility of the collateral, and create roll-over liquidity problems which therefore reduce credit (while increasing loan rates). In appendix D.2 we show how adding a collateral constraint helps to discipline the -short term- behavior of loans and loan rates amplifying the negative impact of the shock on the real economy. In the benchmark model in order to have a sufficiently simple framework with the minimum factors required to explain the transmission of the shock from sovereign debt to equities in the case of sovereign risk, we do not include this mechanism.

Similarly, a more realistic bank representation would allow for some degree of bank home bias mitigating the effect of a global bank with complete integration of bank activities between the core and the periphery. Relaxing the assumption of complete integration would entail more asymmetric responses between the regions (more negative for the periphery and less negative for the core) but would not change the results qualitatively as long as the core and periphery banks are still exposed one-another consistently with the data (ECB, 2012a).

${ }^{43} \mathrm{We}$ refer to flight-to-quality in bond markets by comparing the level of the correlation before 2010, which was very high, to the level during the sovereign debt crisis which fell to approximately 0.2 . Flight-to-quality in the sovereign bond market has received attention in the recent years from the media and scholar. Among others see Barrios et al. (2009) for an analysis of core-periphery sovereign bond spreads.
} 
returns decrease.

Figure 3 - IRFs after a negative maximum sustainable debt-output ratio shock in the periphery.
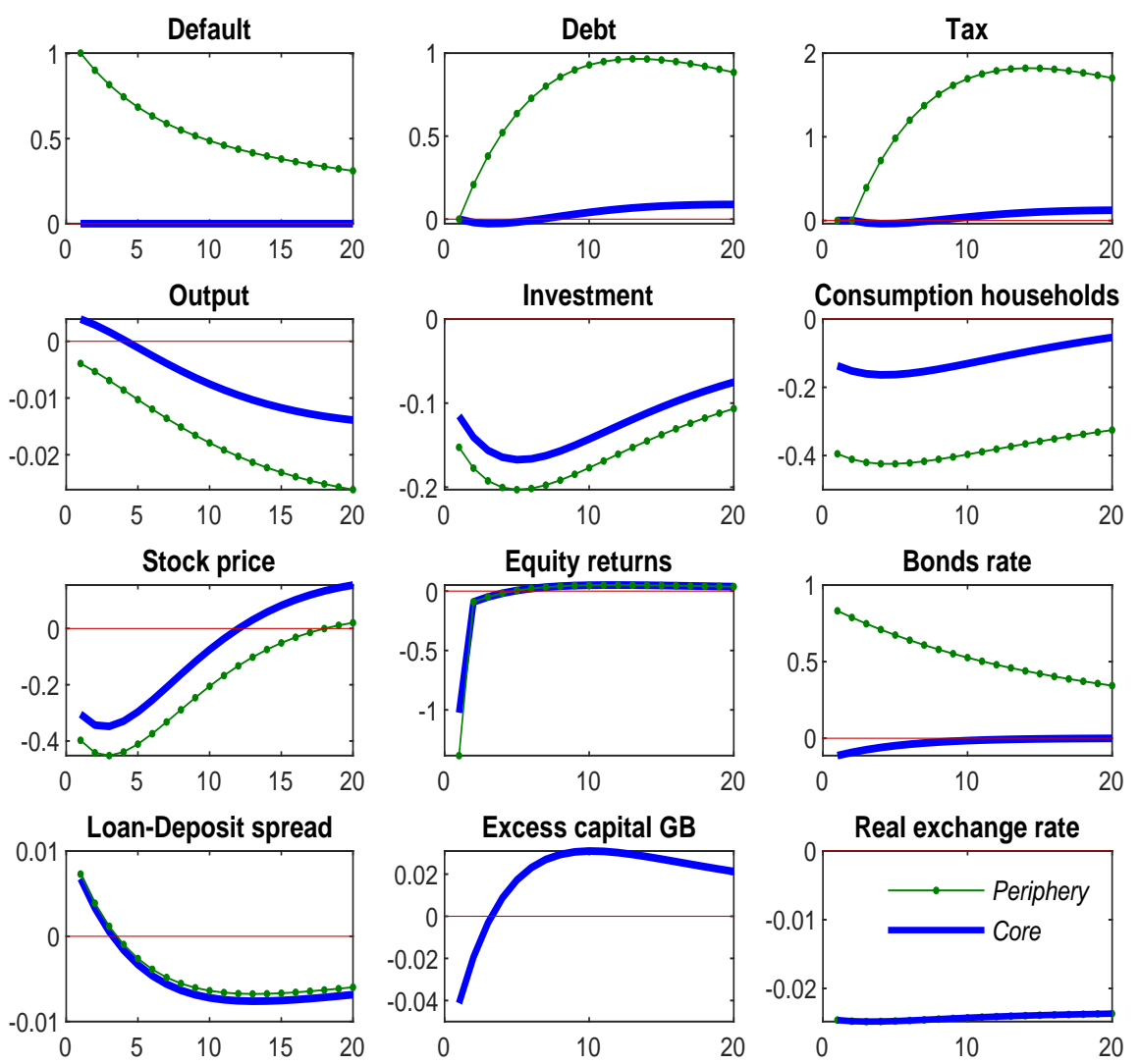

Notes. IRFs show the benchmark model responses for the periphery (dotted line) and the core (solid line) following a $1 \%$ increase in the sovereign default risk. Bank 'excess capital' and 'real exchange rate' are variables common to both regions. The results which deviate from the steady state are expressed respectively in percentage points for rates, and in percentages for the remaining variables.

\subsubsection{Sensitivity analysis}

In this section, we highlight the main mechanism driving the behavior of the stock-bond correlations by conducting a sensitivity analysis on the parameters important to firms' and banks' choices.

On the firm side, the key parameters are $\kappa_{d}$ and $\phi_{i}$. The first controls dividend payouts. When this parameter increases, the dividends paid to households are smaller which affects firms' demand for credit which varies less as firms use more of their retained earnings. Qualitatively, different values of $\kappa_{d}$ do not change the stock-bond correlation behavior. The parameter $\phi_{i}$ controls the volatility of investments. Low values of this parameter means that investments reduce more, driving a decrease in loans but a short-lived increase in dividend payouts (implying lower retained earnings for investments). Since the impact of increased dividend payouts outweighs the decrease in equity 
Figure 4 - Correlation sensitivity to key parameters
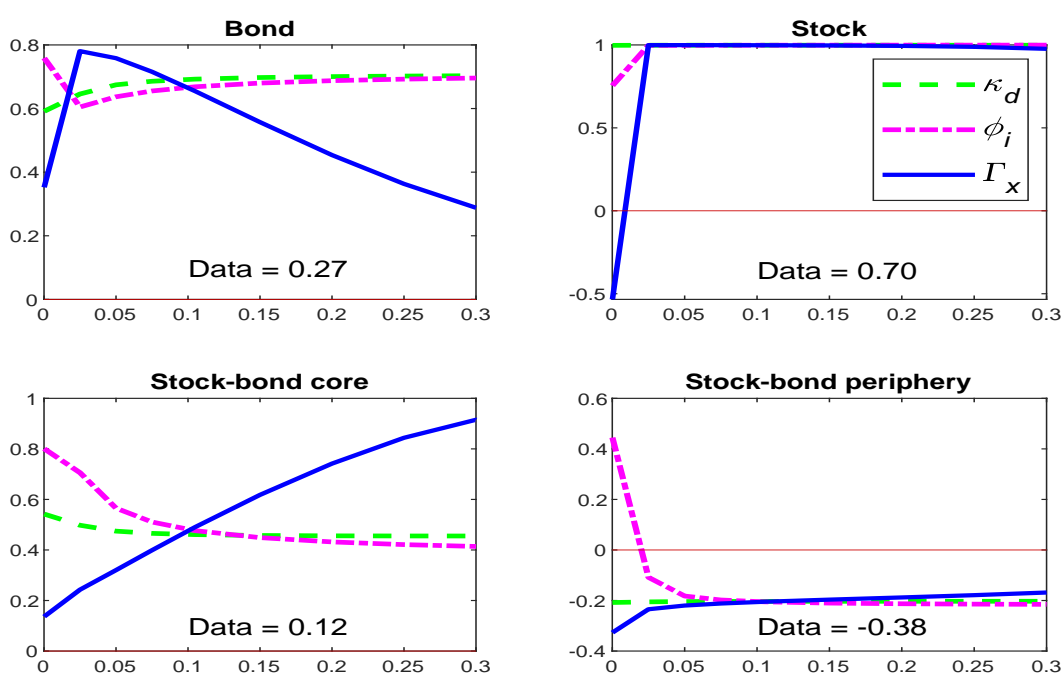

Notes. The graph shows the evolution of correlations ( $y$ axis) to the change in the value of key parameters ( $x$ axis) for the different asset markets (bond, stock and regional stock-bond markets). $\kappa_{d}$ and $\phi_{i}$ affect the choices of entrepreneurs, and monitor, respectively, the behavior of dividend payout and investment adjustments. $\Gamma_{x}$ affects the bank's choices since it changes the cost of leveraging and the balance sheet composition. Correlations are theoretical correlations computed after a $1 \%$ sovereign risk shock. 'Data' are the value of the correlation during the period 2010-2014 as explained in table 1.

prices, the return on equity temporarily increases determining a positive stock-bond correlation in the periphery.

On the bank side, the key parameter is $\Gamma_{x}$ which governs the cost the bank faces when adjusting its balance sheet exposure. In the absence of this friction $\left(\Gamma_{x}=0.0001\right)$, asymmetric shocks imply that the core and the periphery countries experience opposite cycles and asymmetric impacts on their asset markets. In the absence of constraints, the bank freely arbitrages across assets determining an increase in the loan-deposit spread in the periphery country, and a decrease in the loan-deposit spread in the core country which boosts core investment, equity returns, and output. This behavior determines a negative stocks correlation between core and periphery. For higher values of $\Gamma_{x}$ the bank substitutes riskier for risk-free bonds. As the flight to quality between bonds becomes more important, it determines lower bond correlation values and higher core stock-bond correlation values. Figure 4 depicts these behaviors.

\subsection{Empirical simulations}

Figure 5 shows how the model responds to simulations based on the sovereign risk process as the shock estimated from the data. The model matches the behavior of sovereign interest rates, and reproduces the debt dynamics during the sovereign debt crisis. Additionally, it explains a part of the dynamics at the level of financial intermediaries (around 50\% of the loan-deposit spread increase) and the corresponding transmission to i) the real economy, and ii) the equity 


\section{Figure 5 - Empirical simulation}
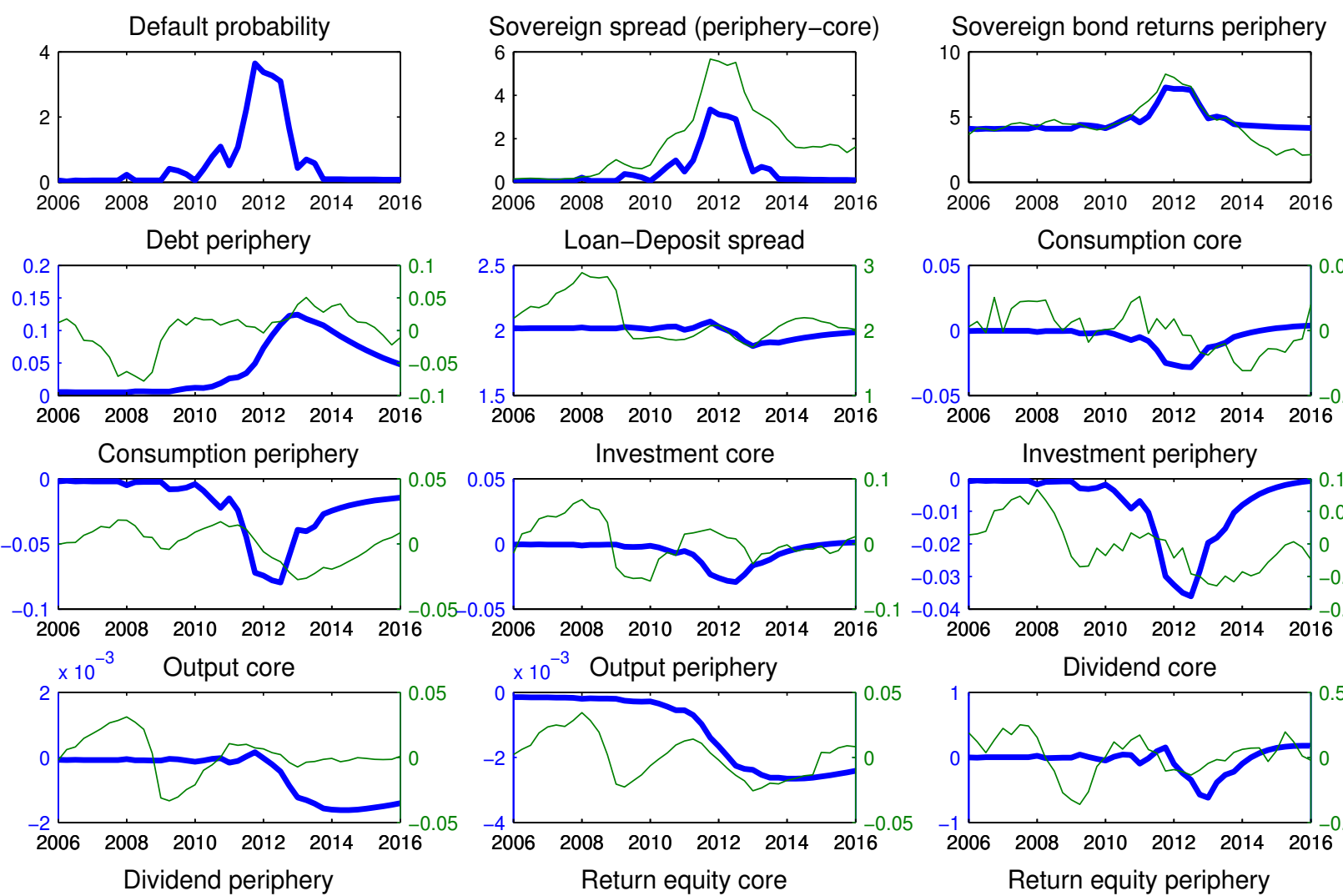

Consumption core
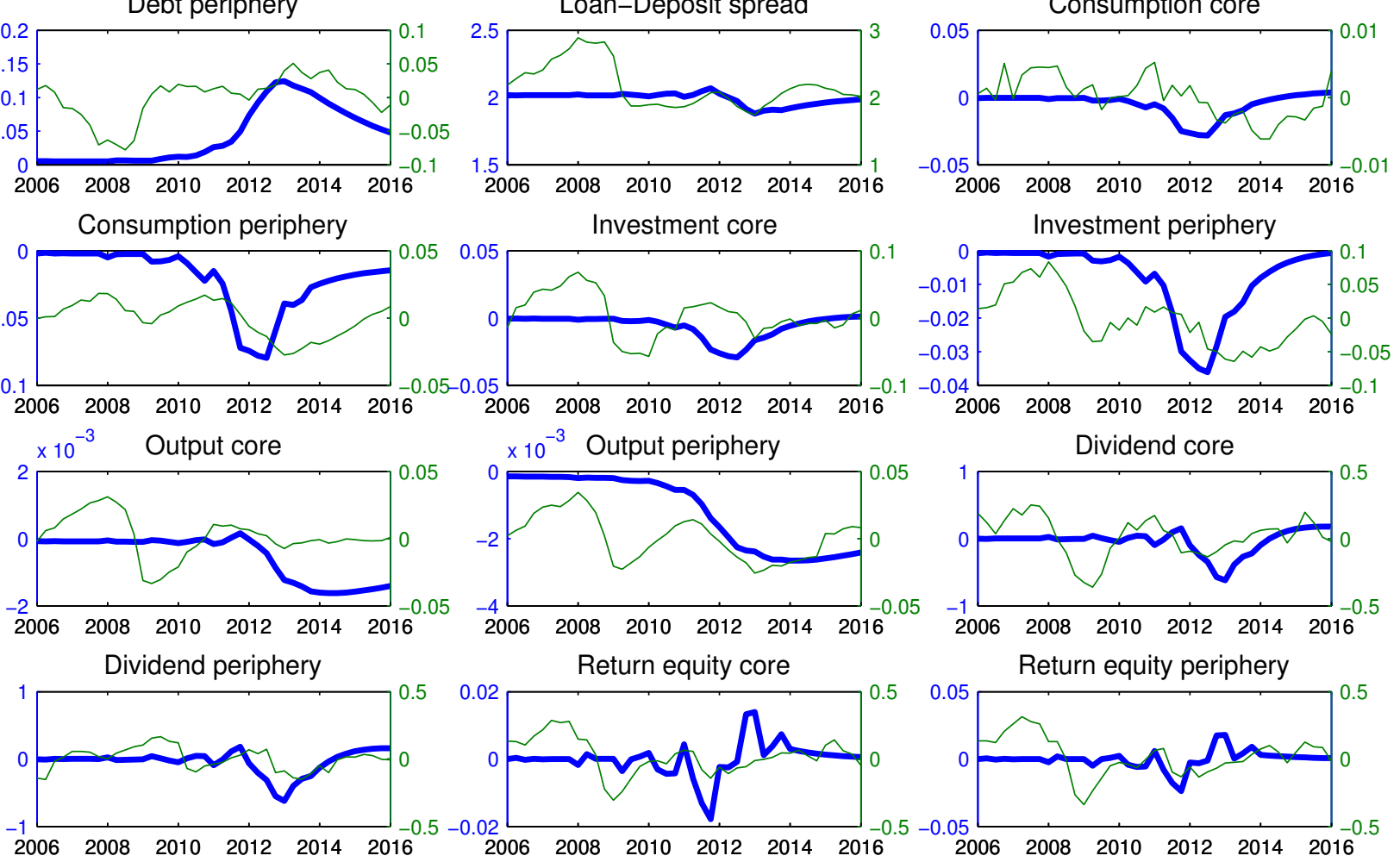

Notes. The graph shows the simulated series (bold line on the far left axes) compared to the actual data (far right axes). Interest rates are expressed in percentages. All the remaining variables are expressed in percentage point log-deviations from the steady state for the simulated data. Actual data except rates (and spreads) are expressed as log-deviations from the stochastic trend (HP filtered).

market. We observe that the sovereign risk shock determines a decrease in investments in both the core and the periphery which explains around $50 \%$ of the decrease in the data. For output the shock explains around $8 \%$ of the drop in the data. On the asset market side, the sovereign risk shock reproduces $11 \%$ and $17 \%$ of the decrease in equity returns', in the core and the periphery respectively, during the sovereign debt crisis. ${ }^{44}$

Table 3 compares theoretical and simulated moments to the correlations in the data between the different regional-asset markets. We see that, the model is able to reproduce the behavior of the periphery and core stock and bond correlations, and the increased divergence in the core-periphery correlations for stock and bond returns as of 2010 , during the sovereign debt crisis.

\footnotetext{
${ }^{44}$ The quantified impacts (model simulations and data) are counted from peak to trough for the period 2010-2014.
} 
Table 3 - Correlation data versus the model

\begin{tabular}{|c|c|c|c|c|c|}
\hline & \multicolumn{3}{|c|}{ Model } & \multicolumn{2}{|c|}{ Data } \\
\hline & \multirow[t]{2}{*}{ Theoretical } & \multicolumn{2}{|c|}{ Simulations } & \multirow[b]{2}{*}{ 2010-2014 } & \multirow[b]{2}{*}{$2000-2016$} \\
\hline & & 2010-2014 & $2000-2016$ & & \\
\hline $\operatorname{corr}\left(R^{b, p}, R^{b, c}\right)$ & 0.67 & -0.22 & 0.13 & 0.27 & 0.70 \\
\hline $\operatorname{corr}\left(R^{S, p}, R^{S, c}\right)$ & 0.99 & 0.99 & 0.99 & 0.70 & 0.76 \\
\hline $\operatorname{corr}\left(R^{b, c}, R^{S, c}\right)$ & 0.48 & 0.84 & 0.74 & 0.12 & 0.16 \\
\hline $\operatorname{corr}\left(R^{b, p}, R^{S, p}\right)$ & -0.19 & -0.39 & -0.32 & -0.38 & -0.09 \\
\hline $\operatorname{corr}(S b, c)-\operatorname{corr}(S b, p)$ & 0.68 & 1.24 & 1.06 & 0.50 & 0.26 \\
\hline
\end{tabular}

$R^{b j}$ is the gross return on sovereign bonds in country $j \in\{c, p\}$ and $R^{S, j}$ the gross return on equity.

Corr $(S b, c)$-corr $(S b, p)$ is the difference between the stock-bond correlation in the core $\left(\operatorname{corr}\left(R^{b, c}, R^{S, c}\right)\right)$ and the periphery $\left(\operatorname{corr}\left(R^{b, p}, R^{S, p}\right)\right)$. The column "Theoretical" presents the theoretical correlations after a $1 \%$ sovereign risk shock as in section 4.2; the column "Simulations" presents the results of the empirical simulations with the estimated sovereign risk shock during the sovereign debt crisis and the whole euro area period; the "Data" column presents correlation data for the same two periods.

\section{Conclusion}

This paper adopted a macroeconomic perspective to study the behavior of euro area asset market co-movements, and in particular, the divergence in core and periphery stock-bond returns correlations during the period 2010-2014. We estimated sovereign risk based on the data and showed that when the model is buffeted by this shock it is able to reconcile the empirical evidence on economic and finance dynamics.

A sovereign risk shock determines a shift in holdings from risky to risk-free sovereign bonds, the so called flight-to-quality which determines an increase in periphery bond returns and a decrease in core bond returns. On the equity market, stock returns decrease in both regions due to a reduction in investments amplified by tighter bank credit conditions. Since the core and periphery banks are strongly related and are exposed to periphery sovereign debt, the reduction in credit affects both core and periphery firms. The disruption to the sovereign bond market, and the high correlations on the stock market ultimately impact in different ways on the core and periphery stock-bond correlations. In the core, the correlation is positive. After a sovereign risk shock, on the one hand interest rates on bonds decrease due to the flight-to-quality towards this asset, and on the other hand, equity returns decrease as firms are affected by a credit crunch which has a negative impact on investment and output. In the periphery, the correlation is negative as sovereign returns spike -given the higher risk- while stock returns decrease. Quantitatively, we find that adding a sovereign risk shock to the model not only reproduces the stylized facts on asset markets but also account for $50 \%$ of the increase in sovereign and loan-deposit spreads, 
$50 \%$ of the decrease in core and periphery investments, and $8 \%$ of the decrease in core and periphery output during the period of the sovereign debt crisis.

This paper is a first attempt to study the impact of a sovereign risk shock on euro area asset markets -including equity- and to explain the underlying macroeconomic dynamics. Future research could focus more on the bank dimension and the impact of bank regulation on asset markets. It might also be worth a closer investigation of the monetary policy implications for central banks. Finally, it would be interesting to extend the asset market dimensions by including in the model bank and corporate debt. On the firm side, introducing corporate debt and allowing for the issue of new equity would refine firms' capital choices and provide new insights for the corporate finance literature.

\section{Bibliography}

Adjemian, S., Bastani, H., Juillard, M., Karamé, F., Mihoubi, F., Perendia, G., Pfeifer, J., Ratto, M., and Villemot, S. (2011). Dynare: Reference manual, version 4. Dynare Working Papers, 1, CEPREMAP.

Alter, A. and Beyer, A. (2014). The dynamics of spillover effects during the european sovereign debt turmoil. Journal of Banking and Finance, 42:134-153.

Altonji, J. G. (1986). Intertemporal substitution in labor supply: Evidence from micro data. Journal of Political Economy, 94 (3):S176-S215.

Andersson, M., Krylova, E., and Vähämaa, S. (2008). Why does the correlation between stock and bond returns vary over time? Applied Financial Economics, 18:139-151.

Auray, S. and Eyquem, A. (2018). On the role of debt maturity in a model with sovereign risk and financial frictions. Macroeconomic Dynamics, forthcoming.

Auray, S., Eyquem, A., and Ma, X. (2018). Banks, sovereign risk and unconventional monetary policies. European Economic Review, 108:153-171.

Barrios, S., Iversen, P., Lewandowska, M., and Setzer, R. (2009). Determinants of intra-euro area government bond spreads during the financial crisis. Economic Papers 388, European Commission Directorate-General for Economic and Financial Affairs.

Beirne, J. and Fratzcher, M. (2013). The pricing of sovereign risk and contagion during the european sovereign debt crisis. Journal of International Money and Finance, 34:60-82.

Bi, H. (2012). Sovereign default risk premia, fiscal limits, and fiscal policy. European Economic Review, 56 (3):389-410.

BIS (2011). The impact of sovereign credit risk on bank funding conditions. Committee on the Global Financial System Papers, 43.

Bocola, L. (2016). The pass-through of sovereign risk. Journal of Political Economy, 124(4):879926. 
Bofondi, M., Carpinelli, L., and Sette, E. (2018). Credit supply during a sovereign debt crisis. Journal of the European Economic Association, 16(3):696-729.

Bohn, H. (1998). The behavior of u.s. public debt and deficits. Quarterly Journal of Economics, 113:949-963.

Campbell, J. Y., Pflueger, C., and Viceira, L. M. (2014). Monetary policy drivers of bond and equity risks. NBER Working Paper 20070.

Chetty, R., Guren, A., Manoli, D., and Weber, A. (2011). Are micro and macro labor supply elasticities consistent? a review of evidence on the intensive and extensive margins. American Economic Review Papers and Proceedings, 75:101-471.

Coeurdacier, N., Kollmann, N., and Martin, R. (2007). International portfolios with supply, demand and redistributive shocks. NBER international Seminar on Macroeconomics 2007, pages 231-263.

Coeurdacier, N. and Rey, H. (2013). Home bias in open economy financial macroeconomic. Journal of Economic Literature, 51(1):63-115.

Collard, F., Habib, M., and Rochet, J.-C. (2015). Sovereign debt sustainability in advanced economies. Journal of the European Economic Association, 13(3):381-420.

Corsetti, G., Kuester, K., Meier, A., and Mueller, G. J. (2013). Sovereign risk, fiscal policy, and macroeconomic stability. The Economic Journal, 123:99-132.

Corsetti, G., Kuester, K., Meier, A., and Mueller, G. J. (2014). Sovereign risk and belief-driven fluctuations in the euro area. Journal of Monetary Economics, 61(C):53-73.

de Grauwe, P. and Ji, Y. (2013). Self-fulfilling crises in the eurozone:an empirical test. Journal of International Money and Finance, 34:15-36.

De Marco, F. (2017). Bank lending and the european sovereign debt crisis. Journal of Financial and Quantitative Analysis, forthcoming.

Delatte, A.-L., Gex, M., and Lopez-Villavicencio, A. (2012). Has the cds market influenced the borrowing cost of european countries during the sovereign crisis? Journal of International Money and Finance, 31:481-497.

ECB (2012a). Euro area cross border financial flows. ECB Monthly Bulletin, September:105-118.

ECB (2012b). Financial integration in europe. European Central Bank Report.

Enders, Z., Kollmann, R., and Muller, G. (2011). Global banking and international business cycles. European Economic Review, 55:407-426.

Faia, E. (2017). Sovereign risk, bank funding and investors' pessimism. Journal of Economic Dynamics and Control, 79:79-96.

Gali, J. and Monacelli, T. (2008). Optimal monetary and fiscal policy in a currency union. Journal of International Economics, 76:116-132.

Garcia-Cicco, J., Pancrazi, R., and Uribe, M. (2010). real business cycles in emerging countries? 
American Economic Review, 100(5):2510-31.

Gould, J. (1968). Adjustment costs in the theory of investment of the firm. The Review of Economic Studies, 35:47-55.

Grammatikos, T. and Vermeulen, R. (2012). Transmission of the financial and sovereign debt crises to the emu: Stock prices, cds spreads and exchange rates. Journal of International Money and Finance, 31:517-533.

Greenwood, J., Hercowitz, Z., and gregory W. Huffman (1988). Investment, capacity utilization, and the real business cycle. American Economic Review, 78(3):402-417.

Guerrieri, L., lacoviello, M., and Minetti, R. (2012). Banks, sovereign debt and the international transmission of business cycles. NBER International Seminar on Macroeconomics.

Jermann, U. and Quadrini, V. (2012). Macroeconomic effects of financial shocks. American Economic Review, 102:238-271.

Jochem, A. and Volz, U. (2011). Portfolio holdings in the euro area - home bias and the role of international, domestic and sector-specific factors. Deutsche Bundesbank discussion paper. Series 1: Economic Studies, No 07.

Juessen, F., Linnemann, L., and Schabert, A. (2016). Default risk premia on government bonds in a quantitative macroeconomic model. Macroeconomic Dynamics, 20 (01):380-403.

Kim, S. J., Moshirian, F., and Wu, E. (2006). Evolution of international stock and bond market integration: Influence of the European Monetary Union. Journal of Banking and Finance, 30(5):1507-1534.

King, R. G., Plosser, C. I., and Rebelo, S. T. (1988). Production, growth and business cycles i. the basic neoclassical model. Journal of Monetary Economics, 21:195-232.

Lucas, R. E. (1967). Adjustment cost and the theory of supply. Journal of Political Economy, 75:321-334.

MaCurdy, T. E. (1981). An empirical model of labor supply in a life-cycle setting. Journal of Political Economy, 89 (6):1059-1085.

Neri, S. and Ropele, T. (2013). The macroeconomic effects of the sovereign debt crisis in the euro area. Banca d'Italia, mimeo.

Perego, E. and Vermeulen, W. (2016). Macro-economic determinants of european stock and government bond correlations: A tale of two regions. Journal of Empirical Finance, 37:214232.

Popov, A. and van Horen, N. (2015). Exporting sovereign stress: Evidence from syndicated bank lending during the euro area sovereign debt crisis. Review of Finance, 19:1825-1866.

Raffo, A. (2008). Net exports, consumption volatility and international business cycle models. Journal of International Economics, 75:14-29.

Roger, S. and Vitek, F. (2011). The global macroeconomic costs of raising bank capital adequacy 
requirements. IMF Working Paper, no. 11/103.

Schmitt-Grohe, S. and Uribe, M. (2012). What's news in business cycle. Econometrica, 80(6):2733-2764.

Slovik, P. and Cournède, B. (2011). Macroeconomic impact of basel iii? OECD Economics Department Working Papers, No. 844, OECD Publishing.

Swanson, E. T. (2015). A macroeconomic model of equities and real, nominal, and defaultable debt. 2015 Meeting Papers 273, Society for Economic Dynamics.

Tobin, J. (1969). A general equilibrium approach to monetary theory. Journal of Money, Credit and Banking, 1:15-29.

van der Kwaak, C. and van Wijnbergen, S. (2014). Financial fragility, sovereign default risk and the limits to commercial bank bail-outs. Journal of Economic Dynamics and Control, 43:218-240. 


\section{Appendix}

\section{A. Individual and aggregated return series}

Figure A.1 presents the disaggregated behavior of sovereign bond and stock markets in the euro zone for the period 2000Q1 to 2017Q3. Figure A.2 presents the aggregate behavior of these series. The series are aggregated at the core and periphery level by weighted average based GDP values for 2004Q4.

Figure A.1 - Behavior of core and periphery bond and stock returns
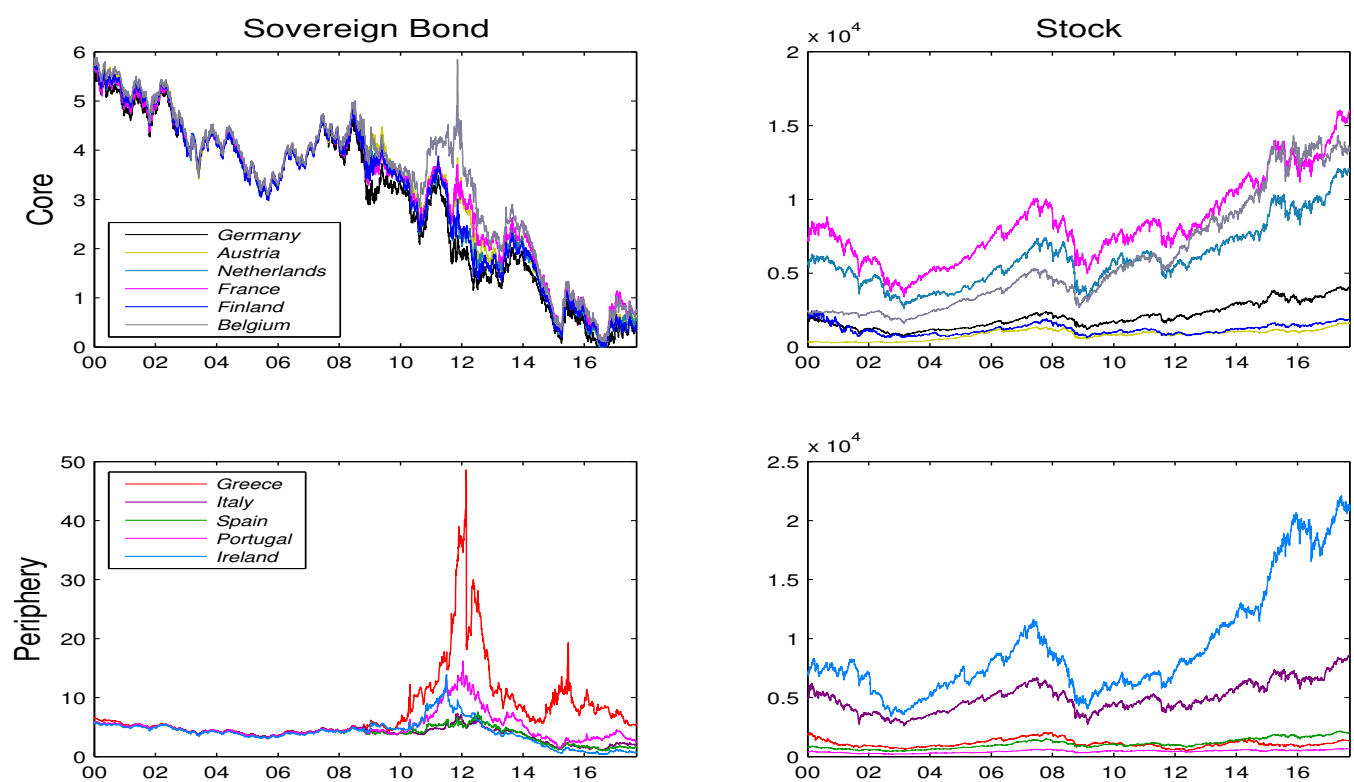

Notes. Stock market series are total return indexes on non-financial firms; bond series are DS benchmark 10 year indexes of yields to redemption expressed in percentage points. Legends for the individual countries refer to the rows.

Data Source: Datastream. 
Figure A.2 - Returns in the euro zone stock-bond markets
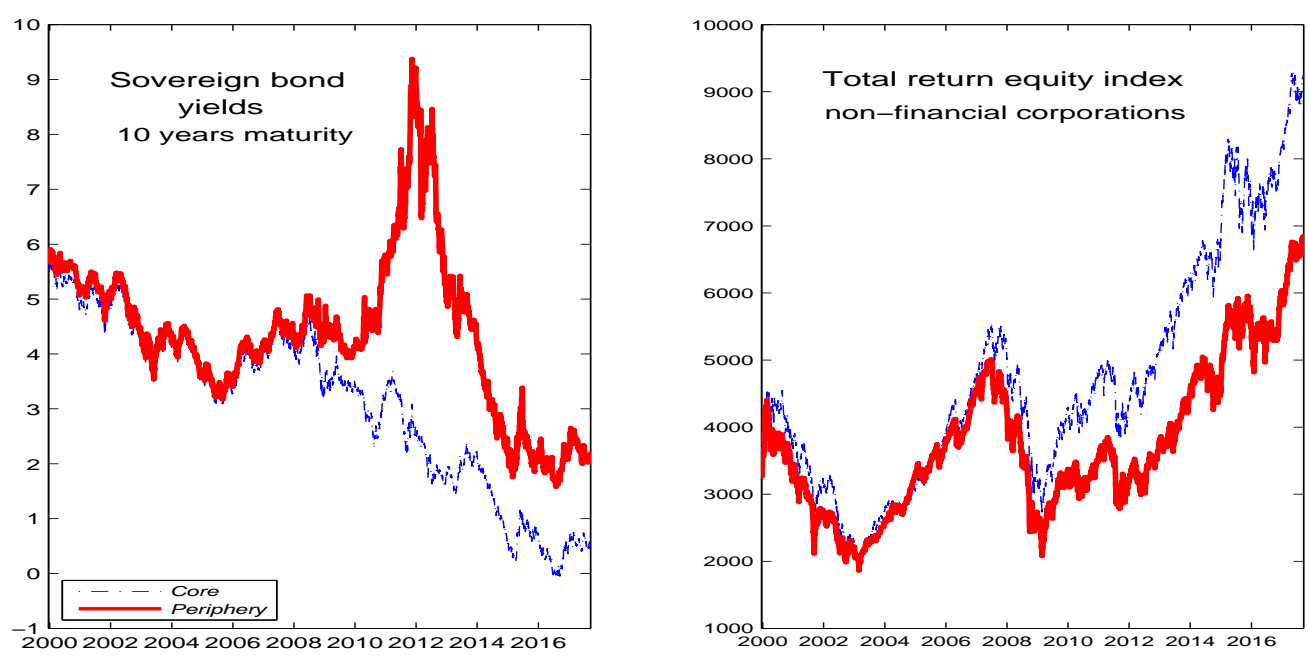

Notes. Stock market series are total return indexes on non-financial firms; bond series are DS benchmark 10 year indexes of yields to redemption expressed in percentage points. Core countries include: Austria, Belgium, Finland, France, Germany and the Netherlands; periphery countries include: Greece, Ireland, Italy, Portugal and Spain. The series are aggregated at the core and periphery levels as weighted averages based on the value of GDP for 2004Q4.

Data source: Datastream and author's calculations. 


\section{B. Quarterly correlations}

Figure B.3 presents the aggregate behavior of the different correlations. The series are aggregated using GDP values for 2004Q4. The correlations obtained are computed on quarterly windows and show the dynamic relations between the returns on stock and the yields on sovereign bonds within the euro zone during the period 2000Q1 to 2017Q3.

Figure B.3 - Realized correlations in the euro zone stock-bond markets
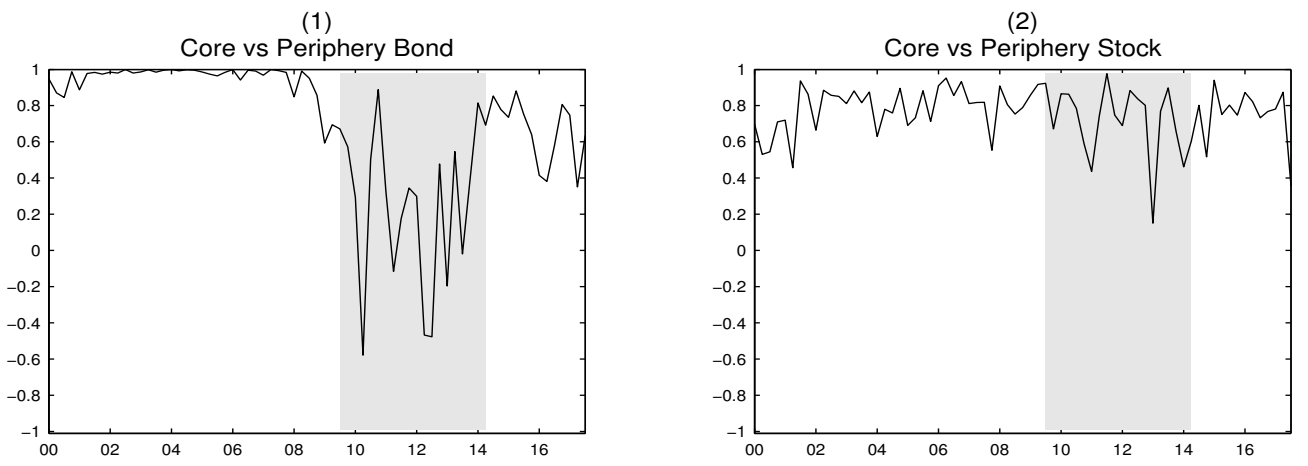

(3)

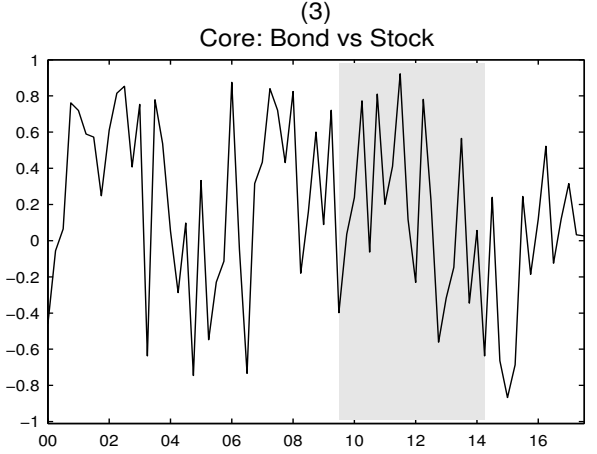

(4)

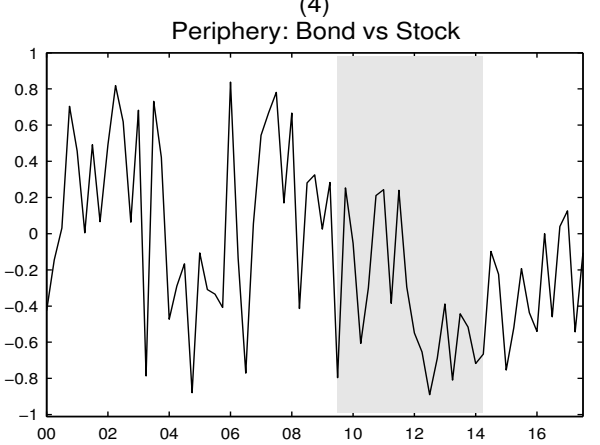

Notes. Stock market series are total return indexes on non-financial firms; bond series are DS benchmark 10 year indexes of yields to redemption. Core countries are: Austria, Belgium, Finland, France, Germany and the Netherlands; periphery countries include: Greece, Ireland, Italy, Portugal and Spain. The series are aggregated at the core and periphery levels as weighted averages based on the value of GDP for 2004Q4. The realized correlations are computed on quarterly windows and show the dynamic relations between the returns on stock and the yields on sovereign bond within the euro zone over the period 2000Q1 to 2017Q3. The shaded areas indicate the period of the sovereign debt crisis.

Data source: Datastream and author's calculations. 


\section{Sovereign risk shock}

In this appendix we explain in detail the methodology used to estimate the sovereign risk shock. The shock we identify is the part of periphery sovereign bond yield' spreads that cannot be explained by the macroeconomic fundamentals. This part which is a measure of risk, is described as the sovereign risk shock, and is introduced in the model as a change to the maximum sustainable level of debt (see section 2.5). Data for the yield series are from Datastream for the 10 year central government bonds. The Yield series used in the estimations are computed as the difference between periphery country yields and Germany's yields ${ }^{45}$. In relation to the independent variables, Debt data are expressed as percentages of GDP, and are taken from Eurostat quarterly national account statistics; current account $(C A)$, real effective exchange rate $(R E E R)$, Growth and total tax revenues (used to construct the ratio of government debt to total tax revenues (Fiscalstance)) are from an OECD database. Periphery countries include the GIIPS: Greece, Ireland, Italy, Portugal and Spain during the period 2000Q1-2017Q2. ${ }^{46}$

\section{C.1. Panel estimation}

For the panel estimation we adhere to the procedure in de Grauwe and Ji (2013). We estimate the following linear panel regression:

$$
\text { Yield }_{i, t}=\alpha+\beta_{1} C A_{i, t}+\beta_{2} \text { Debt }_{i, t}+\beta_{3} R E E R_{i, t}+\beta_{4} \text { Growth }_{i, t}+\alpha_{i}+\tau_{i}+u_{i, t}^{b},
$$

and the non-linear regression:

$$
\begin{aligned}
& \text { Yield }_{i, t}=\alpha+\beta_{1} C A_{i, t}+\beta_{2} \text { Debt }_{i, t}+\beta_{3} R E E R_{i, t}+\beta_{4} \text { Growth }_{i, t}+\beta_{5}\left(D_{e b t_{i, t}}\right)^{2}+\alpha_{i}+\tau_{i}+u_{i, t}^{b}, \\
& \quad \text { for } i=\text { Greece, Ireland, Italy, Portugal, Spain; } \\
& t=2000 q 1, \ldots, 2017 q 2 .
\end{aligned}
$$

Unlike de Grauwe and Ji (2013), we are not interested in assessing the determinants of the yield spread or investigating the existence of a non-linear relation among the macroeconomic fundamentals before and after the crisis. ${ }^{47}$ Instead, we are interested in the (non-linear) unexplained part of risk which we isolate in the residuals after controlling for macroeconomic dynamics. The choice of regressors follows de Grauwe and Ji (2013), equations (1) and (2), and controls also

\footnotetext{
${ }^{45}$ An alternative measure is the CDS on the underlying sovereign bonds. Unfortunately, data available for this variable is restricted to the period 2007-2017 which is shorter than the period considered in this study. Therefore, we use yields in deviation from the benchmark risk-free asset (Germany's bonds) in the sample period 2000Q12017Q2 to proxy for CDS data.

${ }^{46}$ Data on total tax revenues are at annual frequency and available only up to 2015Q4; current account data for Greece and Ireland are available from 2002Q1.

${ }^{47}$ Another difference with respect to de Grauwe and Ji (2013) is that we focus only on a subsample of the countries they consider since we are interested in calibrating the shock for the periphery of the euro zone.
} 
for quarter fixed effects $\tau_{i}$. CA is the current account deficit to GDP ratio, Debt is either the debt-to-GDP ratio or the fiscal space (the ratio of government debt to total tax revenues), $R E E R$ is real effective exchange rate, and Growth is quarter-on-quarter GDP growth rate, $\alpha$ is a constant term and $\alpha_{i}$ is a country fixed effect.

Table C.1 presents the estimation results for equations (32) and (33). ${ }^{48}$ As in de Grauwe and Ji (2013), current account has a negative sign and can be interpreted as an increase in the country's net foreign debt which increases the riskiness. The real effective exchange rate is a measure of competitiveness and can be viewed as early warning of future problems that could turn into real appreciation. Growth has an impact on the country's ability to service its debt. As expected, the sign is negative although not significant since the quarter fixed effects capture all of the variable volatility. Debt in both forms, is positive and significant on its own, and turns negative when interacted with $D e b t^{2}$ which captures the positive but non-linear relation. An increase in debt increases the debt servicing burden which increases the level of liabilities, and thus entails an increasing probability of default. As in de Grauwe and Ji (2013) the best specification of the model, in terms of $R^{2}$, is column (4) from which we take the residuals to compute the sovereign risk shock. ${ }^{49}$

\section{C.2. Sovereign risk shock construction}

Figure C.4 depicts the disaggregated residuals. Since the panel is unbalanced, the length of the residuals series differs from country to country. We account for this by using a changing composition of the periphery shock measure weighted by GDP. ${ }^{50}$ To pass from the aggregated series of residuals to the model shock we need to reconstruct the series $u_{t}^{b}$ in equation (24). The panel residuals can be interpreted as the percentage of the yield spread that is not explained by the fundamentals, as shown in figure 2. To introduce the shock into the model we look for the shock magnitude able to reproduce such spread behaviors. First, we need to reconstruct the maximum debt level series using equation (25) rearranged as follows:

$$
B Y_{t}^{\max }=\frac{B_{t}}{4 Y_{t}}-\operatorname{norminv}\left(\epsilon_{t}^{p}, 0, \sigma^{2}\right)
$$

where $\frac{B_{t}}{4 Y_{t}}$ is aggregated periphery debt to GDP data, $\epsilon_{t}^{p}$ is the series of aggregated residuals and $B Y_{t}^{\max }$ is the maximum sustainable level of debt. We estimate this equation using data for $\frac{B_{t}}{4 Y_{t}}$ in order to reconstruct the maximum sustainable level of debt series implied by the probability of

\footnotetext{
${ }^{48}$ The data sample was cleaned of outliers by removing the top and bottom 1st percentile. The data removed are the negative yields for Ireland in the period 2004Q2-2005Q1, and the very high (positive) values for Greece in the period 2011Q4-2012Q3.

${ }^{49}$ As the sign and magnitude of coefficients remains fairly stable across the different estimations, we use the specification that best explains Yields in terms of $R^{2}$.

${ }^{50}$ As for the remaining calibration, the measure used for aggregation is 2004Q4 GDP values.
} 
Table C.1 - Alternative panel estimations

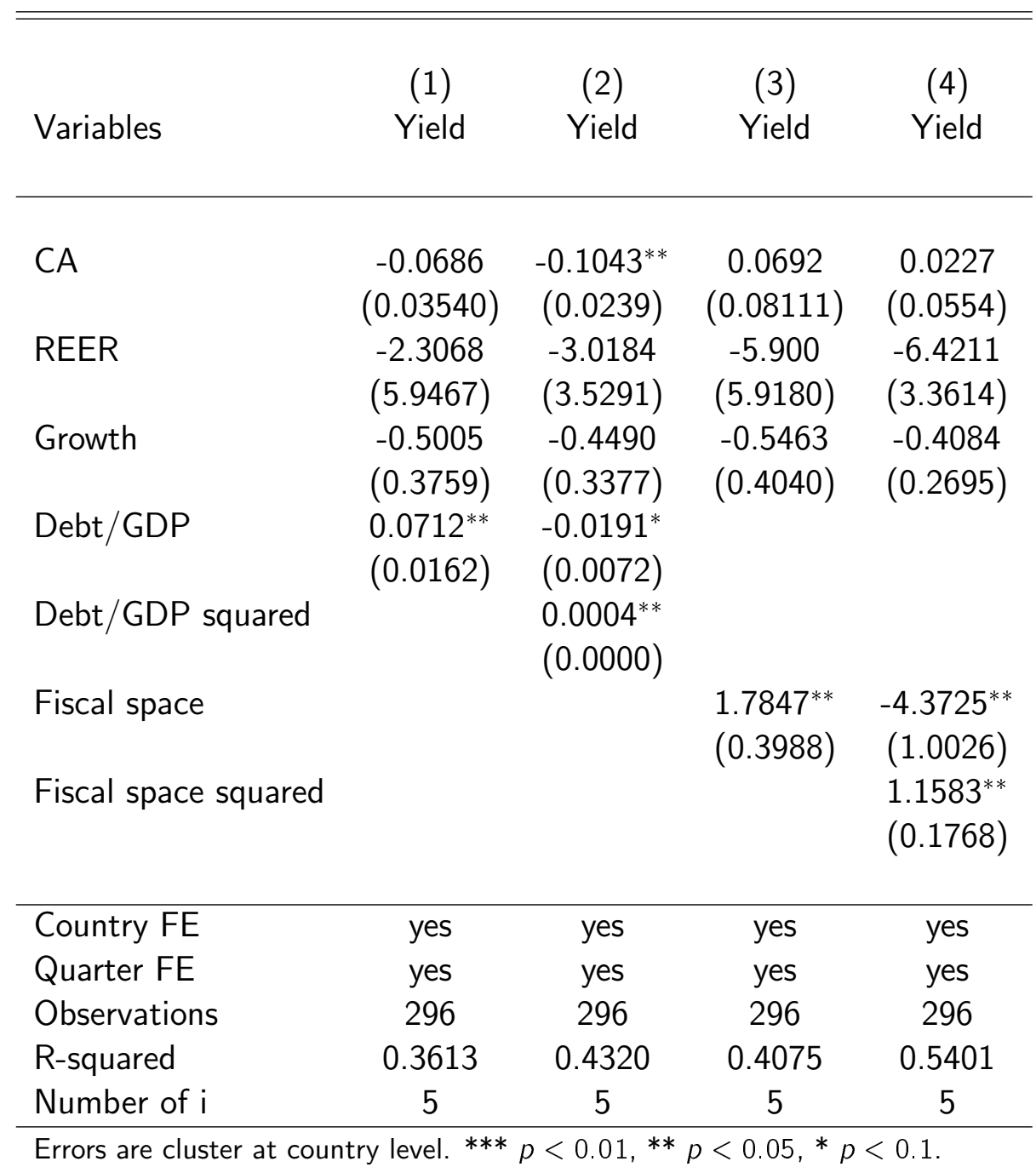

default with the path of debt accumulation. The distance in the data between $\frac{B_{t}}{4 Y_{t}}$ and $B Y_{t}^{\max }$ reduces during the sovereign debt crisis due to a slower increase in the maximum sustainable level of debt with respect to the actual burden of debt to GDP. Having reconstructed the series of $B Y_{t}^{\max }$ we compute $\gamma_{b}$ as the autocorrelation of $B Y_{t}^{\max }$ before the onset of the sovereign debt crisis.

We then simulate the model, introducing the estimated sovereign risk shock as exogenous in order to obtain the corresponding value of $u_{t}^{b}$, the shock to the maximum sustainable level of debt (equation (24)) which reproduces the spread behavior as in figure 2.

Figure C.5 shows the corresponding shock behavior. 
Figure C.4 - Residuals of the panel estimation - unexplained risk -

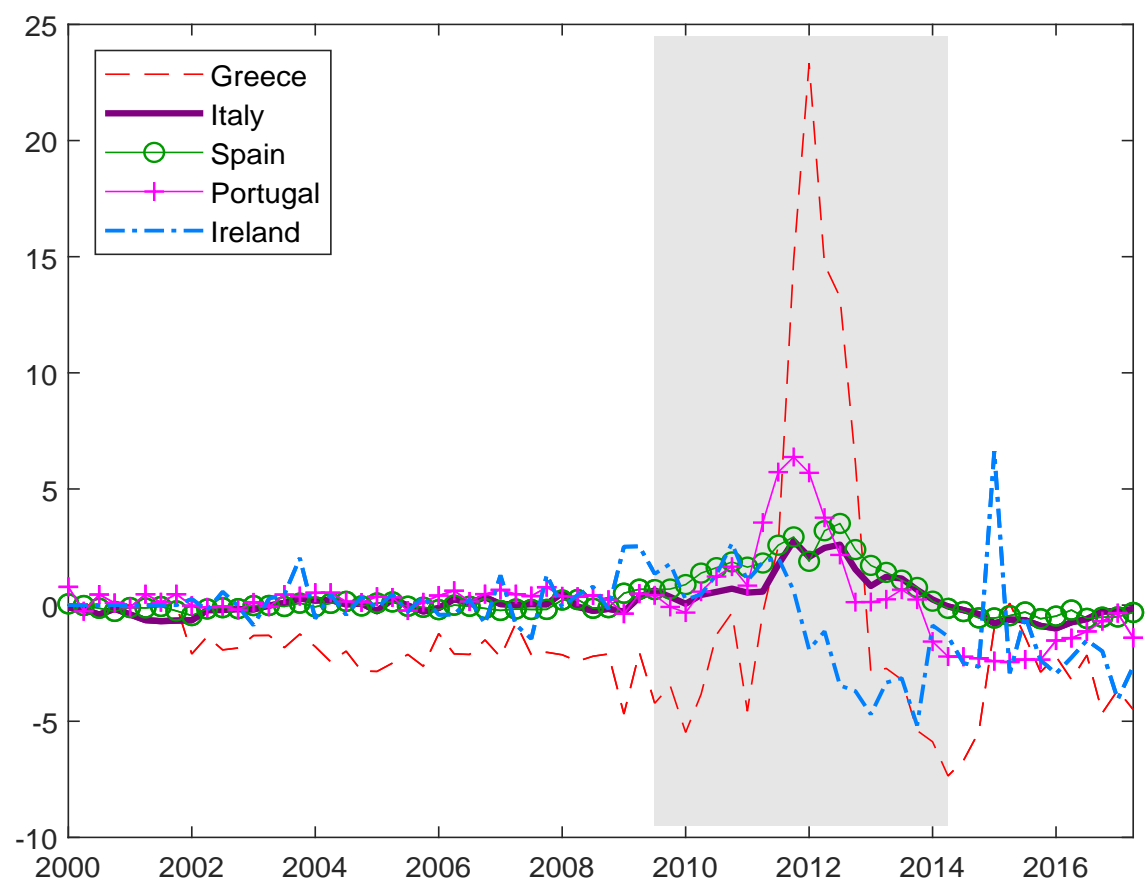

Notes. The graph shows the unexplained part of the sovereign yield spreads (with respect to Germany) expressed in percentage points based on the panel regression in section C.1. Greece and Ireland start in 2002Q1 (missing data are set to zero). The shaded areas represent the period of the sovereign debt crisis.

Data source: Author's calculations

\section{Figure C.5 - Aggregated unexplained riskiness and corresponding shock}

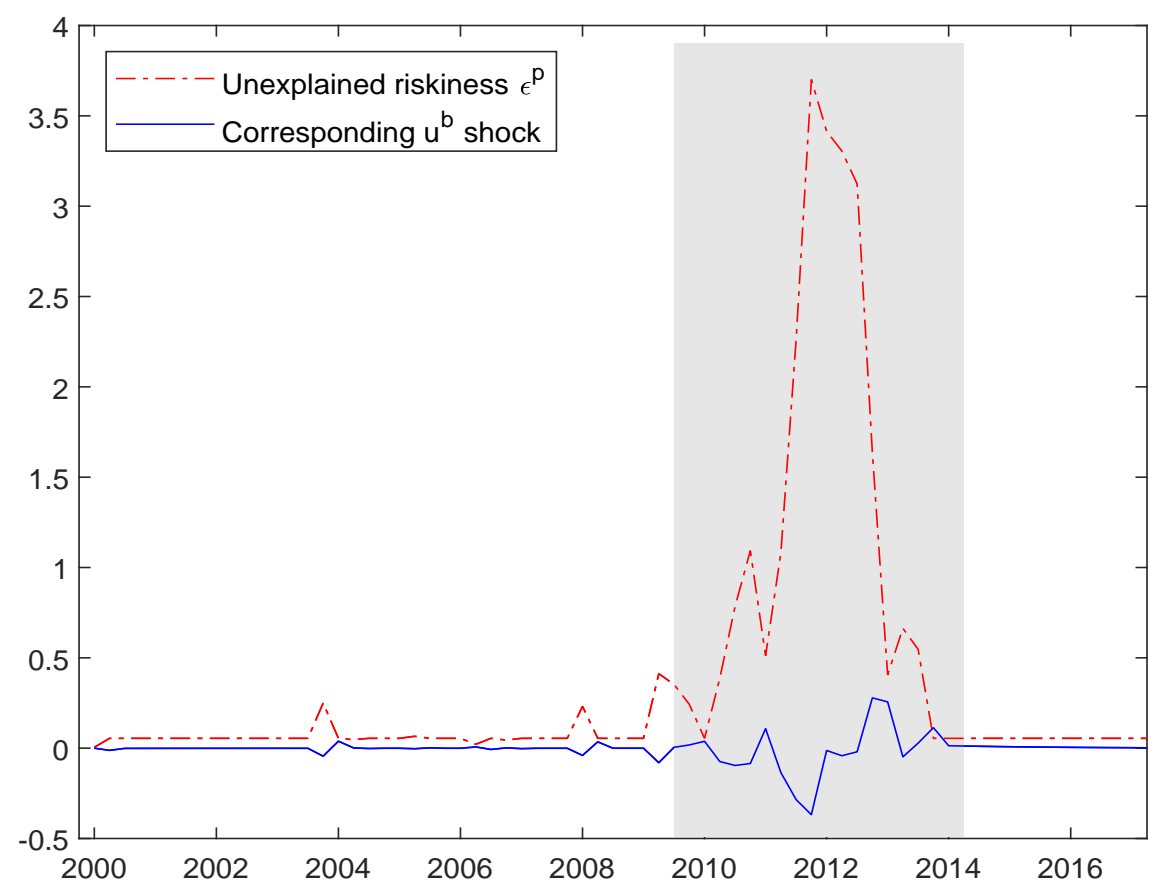

Notes. The graph shows the aggregated series of unexplained riskiness expressed in percentages and computed as explained in section C.1, and the corresponding maximum sustainable debt level shock. The shaded areas represent the period of the sovereign debt crisis.

Data source: Author's calculations 


\section{Sovereign default realization}

In this section we study the implications of relaxing the assumption of ex-post default neutrality by removing transfers and allowing government to default on its debt.

\section{D.1. Default risk versus default realization}

Figure D.6 compares the economy's impulse response functions in the case of default risk and default realization. We can see that, while certain variable responses are qualitatively invariate in the two cases, others are affected strongly and in some cases show counter-intuitive behaviors to actual default. This applies particularly to loans, investments, and output which with default all increase. When faced with default, the bank fully substitutes periphery sovereign bonds for risk-less and unconstrained assets, loans and core sovereign bonds, in order to restore its profits. This determines a stronger decrease in core sovereign interest rates and an increase in loans which is reflected in higher investment and output. This occurs because an important mechanism is missing: the so called collateral sovereign debt channel. This refers to sovereign bonds used as collateral on the interbank market to allow the bank to obtain more credit ultimately to sustain the supply of private credit. When this mechanism is active the supply of loans becomes constrained to the value of the collateral and the strong, counter-intuitive, substitution effect is dampened.

\section{D.2. The role of the collateral constraint}

In this subsection we want to reproduce the effect of a collateral sovereign debt channel. This requires the addition of a highly stylized collateral constraint channel to the bank problem. ${ }^{51}$

The bank problem In this specification of the bank we introduce a second channel of transmission of sovereign risk shock. As highlighted originally in a BIS (BIS, 2011) report, during the sovereign debt crisis banks were affected via both a capital and a collateral channel. The first accounts for balance sheet changes (losses in the case of actual default) as explained in section 2 , the second accounts for the fact that sovereign bonds were used as collateral in the secured interbank market in order to collect funds. As a consequence, a reduction in the volume or quality of collateral reduces the bank's ability to raise funds, roll over liquidity and thus, to sustain the supply of private credit. In this model, since there is no interbank market, we capture this channel of transmission by linking the overall supply of loans directly to both the quantity and the quality of the sovereign bonds used as collateral. The parameter $\nu$ represents the haircut applied to them. In the case of a sovereign risk shock, the collateral constraint introduces a demand

\footnotetext{
${ }^{51}$ To be consistent with the benchmark representation we re-calibrate the dynamic parameter $\kappa_{d}$ to match the volatility of the data as explained in section 3 , increasing it to a value of 1.5 .

The two new parameters, $\nu$ and $\Gamma_{c o l}$, are set respectively to 8 and 1 .
} 
Figure D.6 - Default risk versus default realization benchmark model
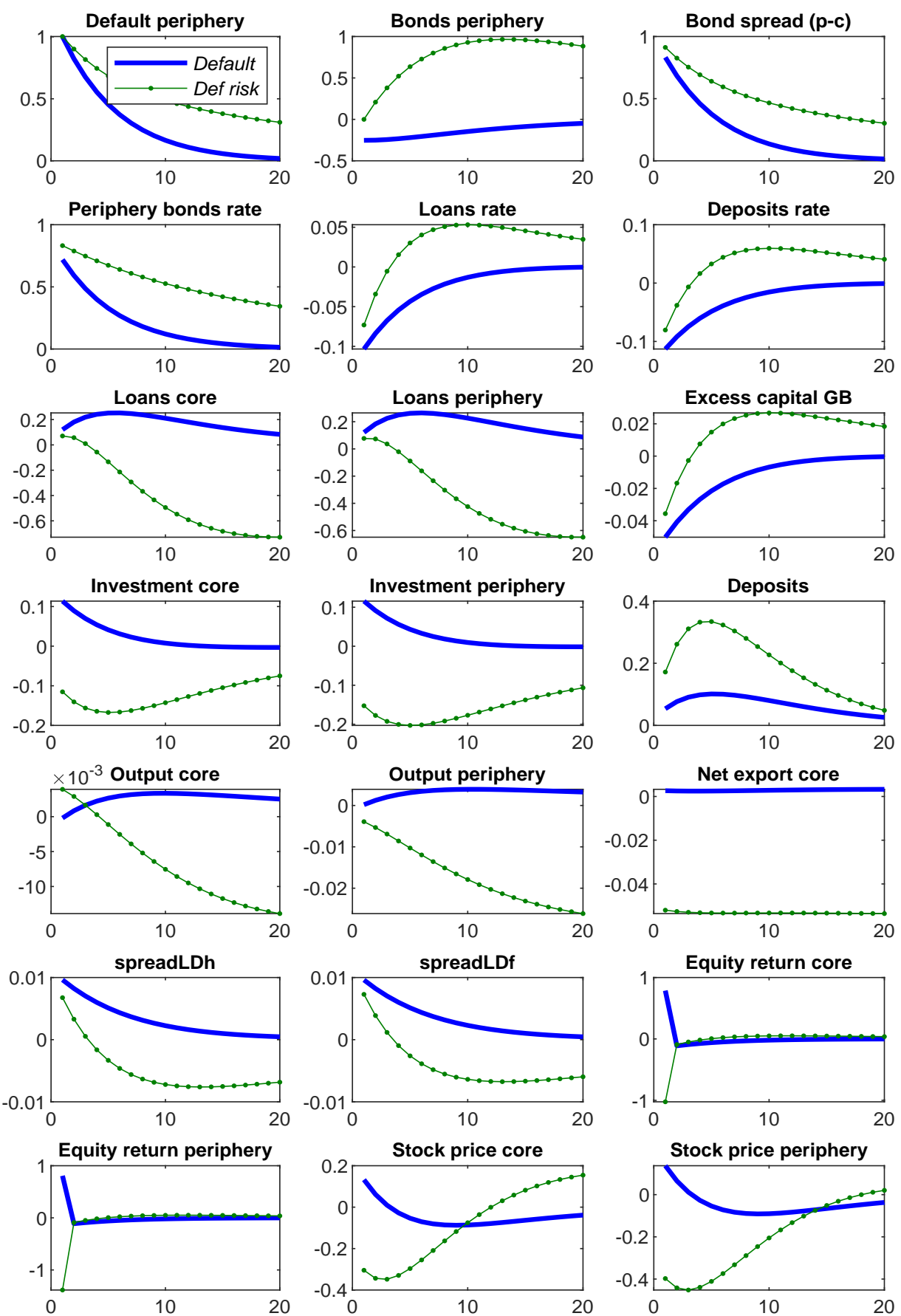

Notes. IRFs show the benchmark model responses after a sovereign risk shock (dotted line) and the response of the model after an actual default (solid line) following a 1\% increase in the sovereign default probability. Results, deviating from the steady state, are expressed respectively in percentage points for rates and in percentages for the remaining variables. 'Deposits' plots the sum of core and periphery deposits. The calibration is the same as in the benchmark specification in section 3 . 
for riskless bonds determining the well-known flight-to-quality in sovereign bond markets, and reduces the supply of credit to capital producers. In the case of actual default, the collateral cost assures a decrease in bank profits, a reduction in the supply of credit to the rest of the economy, and flight-to-quality in the sovereign bond market.

In this specification, the bank is subjected also to a collateral requirement cost which we describe as the collateral constraint:

$$
\frac{\Gamma_{c o l}}{2}\left(\frac{\sum_{j} Q_{c, t}^{j}\left(1-\Delta_{t}^{j}\right)^{\nu} b_{t}^{b, j}}{\sum_{j} Q_{c, t}^{j} L_{t}^{j}}-\frac{\sum_{j} \bar{Q}_{c}^{j} \bar{b}^{b, j}}{\sum_{j} \bar{Q}_{c}^{j} \bar{L}^{j}}\right)^{2} .
$$

Thefore, the bank budget constraint becomes:

$$
\begin{gathered}
\sum_{j} Q_{c, t}^{j} C_{t}^{b, j}+\sum_{j} Q_{c, t}^{j} R_{t-1}^{d, j} D_{t-1}^{j}+\sum_{j} Q_{c, t}^{j} L_{t}^{j}+\sum_{j} Q_{c, t}^{j} b_{t}^{b, j}+\Gamma_{d} \sum_{j}\left(D_{t}^{j}-\bar{D}^{j}\right) \\
+\frac{\Gamma_{l}}{2} \sum_{j}\left(L_{t}^{j}-\bar{L}^{j}\right)^{2}+\frac{\Gamma_{x}}{2}\left(x_{t}\right)^{2}+\frac{\Gamma_{c o l}}{2}\left(\frac{\sum_{j} Q_{c, t}^{j}\left(1-\Delta_{t}^{j}\right)^{\nu} b_{t}^{b, j}}{\sum_{j} Q_{c, t}^{j} L_{t}^{j}}-\frac{\sum_{j} \bar{Q}_{c}^{j} \bar{b}^{b, j}}{\sum_{j} \bar{Q}_{c}^{j} \bar{L}^{j}}\right)^{2} \\
=\sum_{j} Q_{c, t}^{j} D_{t}^{j}+\sum_{j} Q_{c, t}^{j} R_{t-1}^{l, j} L_{t-1}^{j}+\sum_{j} Q_{c, t}^{j}\left(R_{t-1}^{b, j}-\Delta_{t}^{j}\right) b_{t-1}^{b, j}+\sum_{j} Q_{c, t}^{j} H_{t}^{b, j} .
\end{gathered}
$$

The bank maximizes its utility (56) subject to the balance sheet constraint (54) and the budget constraint described above. The FOC now are:

$$
\begin{gathered}
Q_{c, t}^{p}=\frac{1-\vartheta}{\vartheta} \frac{C_{t}^{b, c}}{C_{t}^{b, p}}, \\
\lambda_{t}^{b}\left(Q_{c, t}^{j}-\Gamma_{d}+Q_{c, t}^{j} \Gamma_{x} x_{t}\right)=\beta E_{t} \lambda_{t+1}^{b} Q_{c, t+1}^{j} R_{t}^{d, j}, \\
\lambda_{t}^{b}\left(Q_{c, t}^{j}-\Gamma_{c o l} Q_{c, t}^{j}\left(\frac{\sum_{j} Q_{c, t}^{j}\left(1-\Delta_{t}^{j}\right)^{\nu} b_{t}^{b, j}}{\sum_{j} Q_{c, t}^{j} L_{t}^{j}}-\frac{\sum_{j} \bar{Q}_{c}^{j} \bar{b}^{b, j}}{\sum_{j} \bar{Q}_{c}^{j} \bar{L}^{j}}\right) \frac{\sum_{j} Q_{c, t}^{j}\left(1-\Delta_{t}^{j}\right)^{\nu} b_{t}^{b, j}}{\left(\sum_{j} Q_{c, t}^{j} L_{t}^{j}\right)^{2}}\right. \\
\left.+\Gamma_{l}\left(L_{t}^{j}-\bar{L}^{j}\right)+(1-\gamma) Q_{c, t}^{j} \Gamma_{x} x_{t}\right)=\beta E_{t} \lambda_{t+1}^{b} Q_{c, t+1}^{j} R_{t}^{l, j}, \\
\lambda_{t}^{b}\left(Q_{c, t}^{j}+\Gamma_{c o l} Q_{c, t}^{j}\left(\frac{\sum_{j} Q_{c, t}^{j}\left(1-\Delta_{t}^{j}\right)^{\nu} b_{t}^{b, j}}{\sum_{j} Q_{c, t}^{j} L_{t}^{j}}-\frac{\sum_{j} \bar{Q}_{c}^{j} \bar{b}^{b, j}}{\sum_{j} \bar{Q}_{c}^{j} \bar{L}^{j}}\right) \frac{\left(1-\Delta_{t}^{j}\right)^{\nu}}{\sum_{j} Q_{c, t}^{j} L_{t}^{j}}+Q_{c, t}^{j} \Gamma_{x} x_{t}\right) \\
=\beta E_{t} \lambda_{t+1}^{b} Q_{c, t+1}^{j} R_{t}^{b, j}\left(1-\Delta_{t+1}^{j}\right) .
\end{gathered}
$$

The last two conditions, respectively the Euler equations for loans and sovereign bonds, are now augmented by the collateral constraint term which creates a wedge between the loan and the bond rates. 
Figure D.7 - Default risk versus default realization with the collateral channel
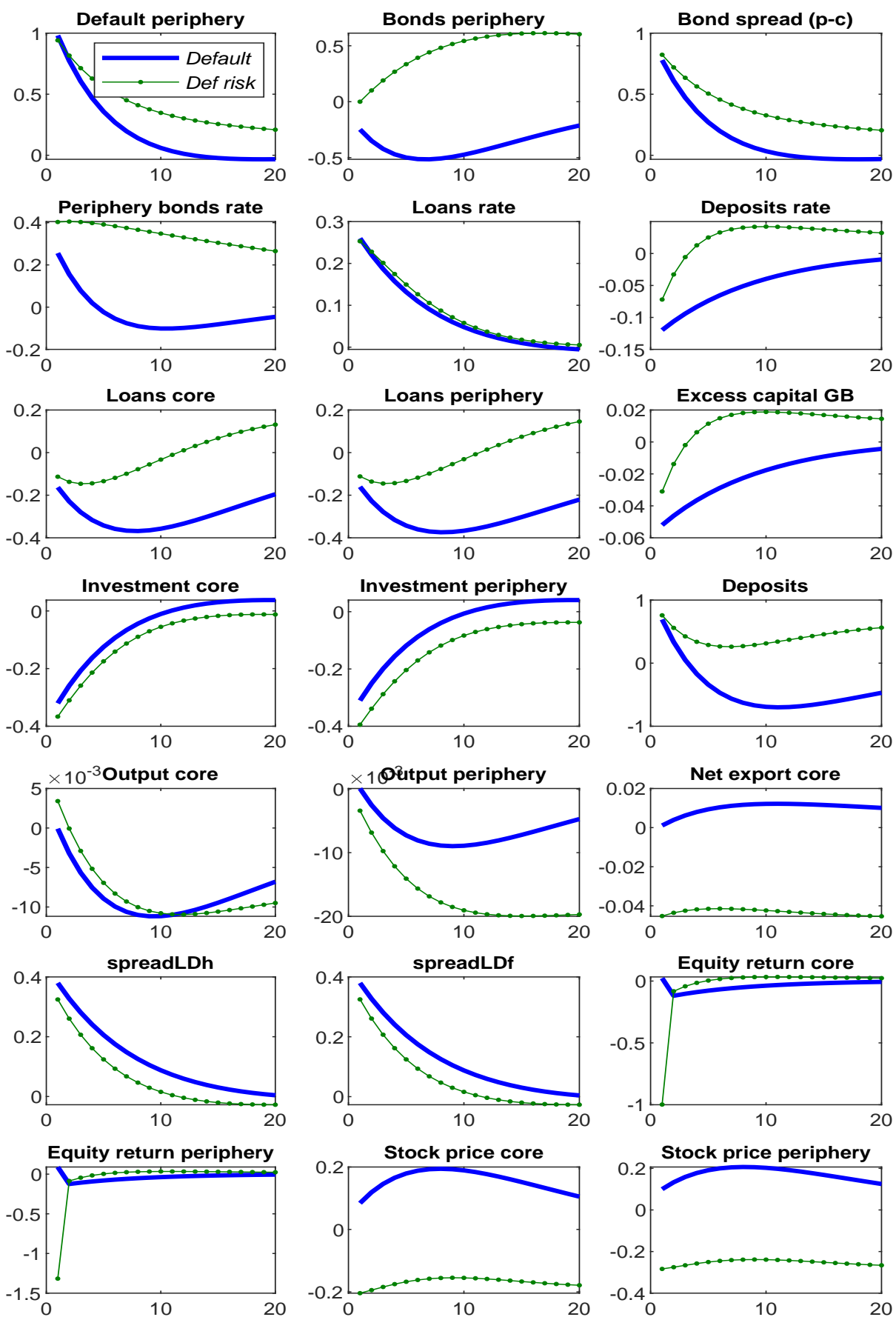

Notes. IRFs show the responses of the model with an active collateral channel after a sovereign risk shock (dotted line) and after an actual default (solid line) after a $1 \%$ increase in sovereign default probability. Results, in deviation from the steady state, are expressed respectively in percentage points for rates and in percent for the remaining variables. 'Deposits' plots the sum of core and periphery deposits. The calibration is as in the benchmark specification of section 3. 
Dynamics and correlations Figure D.7 shows that the introduction of collateral disciplines the behavior of loans, investment, and output which under realization of default now fall. ${ }^{52}$

When the collateral constraint is active, the bank is unable to provide much credit without solid collateral. As a consequence, loans decrease and the bank demands more core safe assets that i) do not require collateral for their purchases and ii) can be used as (safe) collateral.

In the case of sovereign risk (compare the dotted lines in figures D.7 and D.6), the collateral constraint has a smaller impact on dynamics. It disciplines the behavior of loans (which now fall) -as the riskiness of collateral decreases the credit supply- and also loan rates (which now increase). However, the main transmission channel under sovereign risk is not qualitatively affected by the collateral constraint since the decrease in domestic demand determines a fall in investment and output per se which drives equity behavior. What the collateral constraint additionally does, is to quantitatively amplify the benchmark model's dynamics by adding the negative impact of less credit from the banking sector.

Table D.1 shows that the correlations are generally affected very little by the presence of the collateral constraint in the case of risk with the exception of bond correlation where the flight to quality is more pronounced with an active collateral constraint.

\footnotetext{
${ }^{52}$ However, investment and output fall less under realization than under risk. As we saw for the benchmark model, the behavior of the real economy is strongly affected by firms' dynamics (section 4). Figure D.8 shows that a higher value of $\kappa_{d}$ can determine a stronger decrease in investment and output in the case of realization (with respect to risk) which no longer is counter-intuitive. With more stickiness in dividend payout adjustments, investment falls further, determining a more important drop in output under realization than under risk.
}

Figure D.8 - The impact of dividend payout on investment and output
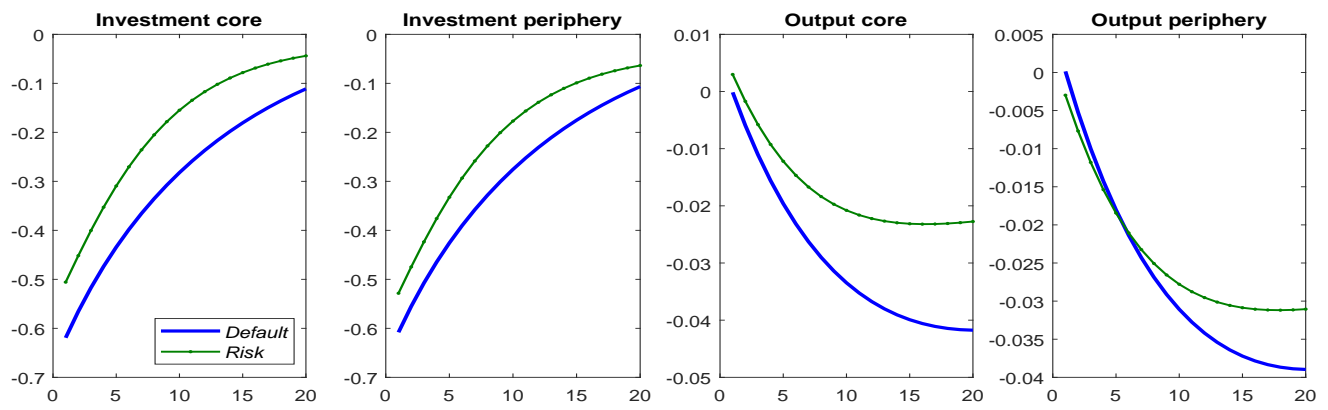

Notes. IRFs show the model responses to an active collateral channel after a sovereign risk shock (dotted line) and after actual default (solid line) following a $1 \%$ increase in the sovereign default probability, with a higher value of $\kappa_{d}$ equal to 4 . Results deviating from the steady state are expressed respectively in percentage points for rates and percentages for the remaining variables.

In this case, we can see clearly the additional impact of actual default (the loss on repayments and a stronger collateral constraint) added to the effect of fear of default or default risk (higher uncertainty around default priced into higher interest rates and faster accumulation of debt). 
Table D.1 - Correlation sensitivity to the collateral constraint

\begin{tabular}{|c|c|c|c|c|c|c|c|c|}
\hline & \multicolumn{2}{|c|}{$\operatorname{corr}\left(R^{b, p}, R^{b, c}\right)$} & \multicolumn{2}{|c|}{$\operatorname{corr}\left(R^{S, p}, R^{S, C}\right)$} & \multicolumn{2}{|c|}{$\operatorname{corr}\left(R^{b, c}, R^{S, c}\right)$} & \multicolumn{2}{|c|}{$\operatorname{corr}\left(R^{b, p}, R^{S, p}\right)$} \\
\hline & Risk & Default & Risk & Default & Risk & Default & Risk & Default \\
\hline Mod & 0.67 & -0.99 & 0.99 & 1 & 0.48 & -0.37 & -0.19 & 0.35 \\
\hline Model collateral & -0.08 & -0.22 & 0.99 & 0.96 & 0.71 & 0.82 & -0.14 & 0.26 \\
\hline
\end{tabular}

$R^{b, j}$ is the gross return on sovereign bonds and $R^{S j}$ the gross return on equity in country $j \in\{c, p\}$.

\section{E. Model details}

The model is an international business cycle model for the euro area. It consists of two regions: core and periphery which we denote, respectively, $c$ and $p$. The two regions are perfectly symmetric except for a higher level of debt to output in the periphery country.

\section{E.1. Households}

In each country $j \in\{c, p\}$, the household budget constraint can be written as:

$$
\begin{gathered}
C_{t}^{j}+D_{t}^{j}+b_{t}^{h, j}+\sum_{i} Q_{j, t}^{i} \rho_{i, t}^{s} S_{i, t}^{j}+\frac{\phi_{s}}{2} \sum_{i} Q_{j, t}^{i} \rho_{i, t}^{s}\left(S_{i, t}^{j}\right)^{2}+\frac{\phi_{b}}{2}\left(b_{t}^{h, j}-\bar{b}^{h, j}\right)^{2} \\
=w_{t}^{j} h_{t}^{j}+R_{t-1}^{d, j} D_{t-1}^{j}+R_{t-1}^{b, j}\left(1-\Delta_{t}^{j}\right) b_{t-1}^{h, j}+\sum_{i} Q_{j, t}^{i}\left(\rho_{i, t}^{s}+d i v_{i, t}\right) S_{i, t-1}^{j} \\
+\Upsilon_{t}^{j}+H_{t}^{h, j}-T_{t}^{j} .
\end{gathered}
$$

Household expected lifetime utility at date $s$ is:

$$
\max E_{s} \sum_{t=s}^{\infty} \beta^{t-s}\left(\ln \left(C_{t}^{j}-\psi_{n} \frac{\left(h_{t}^{j}\right)^{\eta+1}}{\eta+1}\right)+\psi_{d} \ln D_{t}^{j}\right)
$$

$0<\beta<1$ is the subjective discount factor, $\eta$ is the inverse of the inter-temporal elasticity of the supply of labor, and $\psi_{n}, \psi_{d}>0$ are parameters.

The household maximizes (35) subject to (34). It gives the following FOCs:

$$
\begin{gathered}
\psi_{n}\left(h_{t}^{j}\right)^{\eta}=w_{t}^{j}, \\
\lambda_{t}^{j}=\frac{\psi_{d}}{D_{t}^{j}}+E_{t} \beta \lambda_{t+1}^{j} R_{t}^{d, j}, \\
\lambda_{t}^{j}\left(1+\phi_{b}\left(b_{t}^{h, j}-\bar{b}^{h, j}\right)\right)=E_{t} \beta \lambda_{t+1}^{j} R_{t}^{b, j}\left(1-\Delta_{t+1}^{j}\right),
\end{gathered}
$$




$$
\begin{gathered}
\lambda_{t}^{j}\left(1+\phi_{s} S_{j, t}^{j}\right)=E_{t} \beta \lambda_{t+1}^{j}\left(R_{j, t+1}^{S}\right), \\
Q_{j, t}^{i} \lambda_{t}^{j}\left(1+\phi_{s} S_{i, t}^{j}\right)=E_{t} \beta \lambda_{t+1}^{j}\left(R_{i, t+1}^{S}\right) Q_{j, t+1}^{i}, \\
\lambda_{t}^{j}=\left(C_{t}^{j}-\psi_{n} \frac{\left(h_{t}^{j}\right)^{\eta+1}}{\eta+1}\right)^{-1}
\end{gathered}
$$

with $\lambda_{t}^{j}$ being the Lagrangian multiplier associated to the budget constraint.

Equation (36) shows that the wage is equal to the marginal dis-utility of the hours worked. Equations (37), (38), (39) and (40) state that, at equilibrium, marginal costs are equal to the expected marginal income from, deposits, sovereign bonds, domestic and foreign equity respectively. Equation (40) represents the FOC for equity holding for country $j$ households with respect to country $i \in\{c, p\}, i \neq j$ issuers.

\section{E.2. Capital producers}

The capital producers in country $j \in\{c, p\}$ have the following budget constraint:

$$
d i v_{t}^{j}+I_{t}^{j}+\frac{\phi_{i}}{2}\left(I_{t}^{j}-\overline{l j}\right)^{2}+\frac{\kappa_{d}}{2}\left(d i v_{t}^{j}-d \bar{i} v^{j}\right)^{2}+R_{t-1}^{l, j} L_{t-1}^{j}=L_{t}^{j}+r_{t}^{j} K_{t-1}^{j}
$$

and investment increases firms' capital stock $K_{t}^{j}$ according to the law of motion:

$$
K_{t}^{j}=(1-\delta) K_{t-1}^{j}+I_{t}^{j}
$$

They maximize:

$$
\max E_{s} \sum_{t=s}^{\infty}\left(\beta^{e, j}\right)^{t-s} d i v_{t}^{j}
$$

subject to (43) and (42) with $\beta^{e}$ the time varying weighted average of the discount factors of the core and periphery households, expressed in terms of the capital producers' domestic price index:

$$
\begin{aligned}
& \beta^{e, c}=\beta\left(S_{c, t}^{c}\left(\frac{\lambda_{t+1}^{c}}{\lambda_{t}^{c}}\right)+S_{c, t}^{p}\left(\frac{Q_{c, t+1}^{p}}{Q_{c, t}^{p}} \frac{\lambda_{t+1}^{p}}{\lambda_{t}^{p}}\right)\right), \\
& \beta^{e, p}=\beta\left(S_{p, t}^{p}\left(\frac{\lambda_{t+1}^{p}}{\lambda_{t}^{p}}\right)+S_{p, t}^{c}\left(\frac{Q_{c, t}^{p}}{Q_{c, t+1}^{p}} \frac{\lambda_{t+1}^{c}}{\lambda_{t}^{c}}\right)\right) .
\end{aligned}
$$

As equity shares are held internationally, the capital producers are owned by the households in both the core and the periphery countries, and their discount factor accounts for the relative 
importance of each owner's marginal utility. The weights are set according to the time-varying quantities of shares held by each household of one country's capital producers. The FOCs for this problem are:

$$
\begin{gathered}
\lambda_{t}^{e, j}=E_{t} \beta^{e, j} \lambda_{t+1}^{e, j} R_{t}^{l, j}, \\
\lambda_{t}^{e, j} q_{t}^{j}=E_{t} \beta^{e, j} \lambda_{t+1}^{e, j}\left(r_{t+1}^{j}+(1-\delta) q_{t+1}^{j}\right), \\
l_{t}^{j}=\bar{l}^{j}+\frac{1}{\phi_{l}}\left(q_{t}^{j}-1\right), \\
\lambda_{t}^{e, j}=\frac{1}{1+\kappa_{d}\left(d i v_{t}^{j}-d \bar{i} v^{j}\right)} .
\end{gathered}
$$

Equation (44) states that at equilibrium, the marginal income from loans is equal to the expected marginal cost weighted by the households discount factor. Equation (45) defines the shadow value of capital, $q_{t}^{j}$, as the expected discounted value of the marginal profit from one additional unit of capital. Equation (46) relates the shadow price of capital to investments.

\section{E.3. Nonfinancial firms}

In each country $j \in\{c, p\}$ firms are perfectly competitive. The intermediate $j$ firm produces a good that is sold in both the domestic and the foreign country. A final firm in each country combines the intermediate goods from the $j$ and $-j$ countries into a final good.

Final firms In each region the demand for goods is a composite of the home and foreign intermediate goods. The aggregate demand for country $j$ is:

$$
A^{j}=\left(\frac{A_{j}^{j}}{1-\alpha}\right)^{(1-\alpha)}\left(\frac{A_{-j}^{j}}{\alpha}\right)^{\alpha},
$$

where $A_{j}^{j}$ and $A_{-j}^{j}$ are respectively the demands of the final firm $j$ for goods $j$ and $-j$. The optimal demand for each variety of the final good is given by the following FOC: 53

$$
\begin{array}{rlrl}
A_{c, t}^{c} & =(1-\alpha) \frac{1}{\phi_{t}^{c}} A_{t}^{c}, & A_{p, t}^{p} & =(1-\alpha) \frac{1}{\phi_{t}^{p}} A_{t}^{p}, \\
A_{p, t}^{c}=\alpha \frac{1}{Q_{c, t}^{p} \phi_{t}^{p}} A_{t}^{c}, & A_{c, t}^{p}=\alpha \frac{Q_{c, t}^{p}}{\phi_{t}^{c}} A_{t}^{p} .
\end{array}
$$

\footnotetext{
${ }^{53}$ Optimal demands are the solution to final firm maximization problem:
}

$\left\{A_{j, t}^{j}, A_{-j, t}^{j}\right\}_{t=0}^{\infty}$ to maximize $P_{t}^{j} A_{t}^{j}-p_{j, t}^{j} A_{j, t}^{j}-p_{-j, t}^{j} A_{-j, t}^{j}$. 
The welfare based price index (for both regions) corresponding to these preferences is:

$$
P_{t}^{j}=\left(p_{j, t}^{j}\right)^{(1-\alpha)}\left(p_{-j, t}^{j}\right)^{\alpha}
$$

Dividing by $P^{j}$, and by the law of one price, the price index can be simplified as:

$$
\begin{aligned}
1 & =\phi_{t}^{j} \phi_{t}^{-j}, \\
Q_{j, t}^{-j} & =\left(\phi_{t}^{j}\right)^{\frac{2 \alpha-1}{\alpha}},
\end{aligned}
$$

with $\phi_{t}^{j}=\frac{p_{j, t}^{j}}{P_{t}^{j}}$ being the share of domestic produced goods' prices in the domestic price index and $Q_{c, t}^{p}=\frac{e_{t} P_{t}^{p}}{P_{t}^{c}}$ being the real exchange rate when the core country is the numeraire. The nominal exchange rate $e_{t}$ is set to 1 because the two economies belong to the same currency union.

Intermediate firms There is a competitive non financial sector in the economy which produces a tradable good under a Cobb-Douglass production function. The maximization problem of the firms reads:

$$
\max \Upsilon_{t}^{j}
$$

$$
\begin{aligned}
\text { s.t. } \Upsilon_{t}^{j} & =\phi_{t}^{j} Y_{t}^{j}-w_{t}^{j} h_{t}^{j}-r_{t}^{j} K_{t-1}^{j}, \\
Y_{t}^{j} & =Z_{t}^{j}\left(K_{t}^{j}\right)^{\mu}\left(h_{t}^{j}\right)^{1-\mu},
\end{aligned}
$$

where $Z_{t}^{j}=\bar{Z}^{j}=1$. The FOC for this maximization problem equates to the marginal productivity of factors and their marginal cost:

$$
\begin{aligned}
r_{t}^{j} & =\mu \frac{\phi_{t}^{j} Y_{t}^{j}}{K_{t-1}^{j}} \\
w_{t}^{j} & =(1-\mu) \frac{\phi_{t}^{j} Y_{t}^{j}}{h_{t}^{j}}
\end{aligned}
$$

\section{E.4. Banking sector}

The banking sector specification follows Enders et al. (2011). The international and perfectly competitive bank is located in the core but trades with all countries $j \in\{c, p\}$. The bank has to set aside a fraction $\gamma$ of loans as own capital. The corresponding bank balance sheet constraint is:

$$
(1-\gamma) \sum_{j} Q_{c, t}^{j} L_{t}^{j}+\sum_{j} Q_{c, t}^{j} b_{t}^{b, j}=\sum_{j} Q_{c, t}^{j} D_{t}^{j}+x_{t}
$$

If the bank deviates from legal requirements $\left(x_{t}=0\right)$ pays a cost. The bank budget constraint 
is:

$$
\begin{gathered}
\sum_{j} Q_{c, t}^{j} C_{t}^{b, j}+\sum_{j} Q_{c, t}^{j} R_{t-1}^{d, j} D_{t-1}^{j}+\sum_{j} Q_{c, t}^{j} L_{t}^{j}+\sum_{j} Q_{c, t}^{j} b_{t}^{b, j}+\Gamma_{d} \sum_{j}\left(D_{t}^{j}-\bar{D}^{j}\right) \\
+\frac{\Gamma_{l}}{2} \sum_{j}\left(L_{t}^{j}-\bar{L}^{j}\right)^{2}+\frac{\Gamma_{x}}{2}\left(x_{t}\right)^{2} \\
=\sum_{j} Q_{c, t}^{j} D_{t}^{j}+\sum_{j} Q_{c, t}^{j} R_{t-1}^{l, j} L_{t-1}^{j}+\sum_{j} Q_{c, t}^{j} R_{t-1}^{b, j}\left(1-\Delta_{t}^{j}\right) b_{t-1}^{b, j}+\sum_{j} Q_{c, t}^{j} H_{t}^{b, j} .
\end{gathered}
$$

The bank utility is:

$$
\max E_{s} \sum_{t=s}^{\infty} \beta^{t-s}\left(C_{t}^{b, c}\right)^{\vartheta}\left(C_{t}^{b, p}\right)^{1-\vartheta}
$$

where $\vartheta$ is the elasticity of utility with respect to country $c$ consumption goods. The bank maximizes (56) subject to (54) and (55). The FOC are:

$$
\begin{gathered}
\lambda_{t}^{b}=\vartheta \frac{\left(C_{t}^{b, c}\right)^{\vartheta}\left(C_{t}^{b, p}\right)^{1-\vartheta}}{C_{t}^{b, c}}, \\
Q_{c, t}^{p}=\frac{1-\vartheta}{\vartheta} \frac{C_{t}^{b, c}}{C_{t}^{b, p}}, \\
\lambda_{t}^{b}\left(Q_{c, t}^{j}-\Gamma_{d}+Q_{c, t}^{j} \Gamma_{x} x_{t}\right)=\beta E_{t} \lambda_{t+1}^{b} Q_{c, t+1}^{j} R_{t}^{d, j}, \\
\lambda_{t}^{b}\left(Q_{c, t}^{j}+\Gamma_{l}\left(L_{t}^{j}-\bar{L}^{j}\right)+(1-\gamma) Q_{c, t}^{j} \Gamma_{x} x_{t}\right)=\beta E_{t} \lambda_{t+1}^{b} Q_{c, t+1}^{j} R_{t}^{l, j}, \\
\lambda_{t}^{b}\left(Q_{c, t}^{j}+Q_{c, t}^{j} \Gamma_{x} x_{t}\right)=\beta E_{t} \lambda_{t+1}^{b} Q_{c, t+1}^{j} R_{t}^{b, j}\left(1-\Delta_{t+1}^{j}\right) .
\end{gathered}
$$

Equation (58) relates the ratio of bank's consumption for the two regions to the ratio of relative price indexes. Equations (59), (60), (61) represent respectively the Euler equation for deposits, loans and sovereign bonds.

\section{E.5. Government}

Government consumption in each region $j \in\{c, p\}, G^{j}$, is financed via lump-sum taxes, $T_{t}^{j}$, from households and via public debt, $B_{t}^{j}$, according to:

$$
\begin{aligned}
G^{j}+H_{t}^{h, j}+H_{t}^{b, j}+R_{t-1}^{b, j}\left(1-\Delta_{t}^{j}\right) B_{t-1}^{j} & =B_{t}^{j}+T_{t}^{j}, \\
T_{t}^{j} & =\bar{T}+\tau\left(B_{t}^{j}-\bar{B}\right), \\
H_{t}^{h, j} & =\Delta_{t}^{j} R_{t-1}^{b, j} b_{t-1}^{h, j}, \\
H_{t}^{b, j} & =\Delta_{t}^{j} R_{t-1}^{b, j} b_{t-1}^{b, j} .
\end{aligned}
$$


where $G^{j}$ is assumed to be constant and $H_{t}^{h, j}, H_{t}^{b, j}$ are lump-sum transfers, respectively to households and banks which compensate bond holders for losses due to sovereign default.

Default For the default specification we adhere to the methodology used by Corsetti et al. (2013) and van der Kwaak and van Wijnbergen (2014). The existence of an exogenous fiscal limit on the economy, translates into a maximum level of sovereign debt-to-output ratio $B Y_{t}^{\max }$ which the government is able to service. This maximum sustainable level is stochastic and follows:

$$
B Y_{t}^{\max }=\overline{B Y^{\max }}+\gamma_{b}\left(B Y_{t-1}^{\max }-B \bar{Y}^{\max }\right)+u_{t}^{b}
$$

where $0<\gamma_{b}<1$ is the autoregressive component, and $u_{t}^{b}$ is a i.i.d. shock. Let us define $\tilde{B}_{t}^{j}$ as the level of debt in the economy when no default occurs:

$$
G_{t}^{j}+R_{t-1}^{b, j} B_{t-1}^{j}=T_{t}^{j}+\tilde{B}_{t}^{j}
$$

If this level of debt-to-output $\tilde{B}_{t}^{j} /\left(4 Y_{t}^{j}\right)$ is lower (respectively higher) than the maximum sustainable level $B Y_{t}^{\max }$, the government does not (respectively does) default. We define the default decision $\Delta_{t}$ as:

$$
\Delta_{t}= \begin{cases}1 & \text { with probability } \epsilon_{t}^{j} \\ 0 & \text { with probability } 1-\epsilon_{t}^{j}\end{cases}
$$

and the probability of default is approximated by the continuous normal cdf:

$$
\epsilon_{t}^{j}=F\left(\frac{\tilde{B}_{t}^{j}}{4 Y_{t}^{j}}-B Y_{t}^{\max } ; 0, \sigma^{2}\right)=\Phi\left(\frac{\frac{\tilde{B}_{t}^{j}}{4 Y_{t}^{j}}-B Y_{t}^{\max }}{\sigma}\right)
$$

where $\sigma^{2}>0$ represents the variance and $\Phi($.$) is the standard normal cdf.$

\section{E.6. Closing the model}

Asset market clearing conditions The sovereign bond market clearing condition for country $j \in\{c, p\}$ is:

$$
B_{t}^{j}=b_{t}^{h, j}+b_{t}^{b, j}
$$

where $b_{t}^{h, j}$ and $b_{t}^{b, j}$ are the quantities of bonds held by households and the bank.

The equity market clearing condition for country $i \in\{c, p\}$ issuing and country $j \in\{c, p\}$ holding is:

$$
1=S_{i, t}^{j}+S_{i, t}^{-j}
$$

implying that there is a fixed number of shares traded in the economy normalized to 1 . 


\section{E.7. Good market clearing condition}

Let's define the domestic demand for country $j$ as:

$$
A_{t}^{j}=C_{t}^{j}+C_{t}^{b, j}+I_{t}^{j}+G_{t}^{j}+\operatorname{cost} s_{t}^{j}
$$

where $\operatorname{costs} s_{t}^{j}$ collects all adjustment and operating costs borne by households, capital producers, and firms in country $j$. $\operatorname{cost}_{t}^{c}$ also include the costs related to the bank.

The good market clearing condition for each region $j$ is:

$$
Y_{t}^{j}=A_{j, t}^{j}+A_{j, t}^{-j}
$$

and the resource constraint for the two-country economy is:

$$
\sum_{j} \phi_{t}^{j} Q_{c, t}^{j} Y_{t}^{j}=\sum_{j} Q_{c, t}^{j} A_{t}^{j}
$$

